\title{
Pathogenesis of Herpes Stromal Keratitis: Immune Inflammatory Response Mediated by Inflammatory Regulators
}

\author{
Li Wang ${ }^{1,2}$, Runbiao Wang $^{2}$, Chuyang $\mathrm{Xu}^{1}$ and Hongyan Zhou ${ }^{1 *}$ \\ ${ }^{1}$ Department of Ophthalmology, China-Japan Union Hospital of Jilin University, Changchun, China, ${ }^{2}$ Department of \\ Ophthalmology, Jilin City Central Hospital, Jilin, China
}

OPEN ACCESS

Edited by:

Linda F. Van Dyk

University of Colorado Denver,

United States

Reviewed by:

Barry Tyrrell Rouse,

The University of Tennessee, Knoxville,

United States

John R. Sedy,

Sanford Burnham Prebys Medical

Discovery Institute, United States

${ }^{*}$ Correspondence:

Hongyan Zhou

zhouhongyan7301@sina.com

Specialty section:

This article was submitted to

Viral Immunology

a section of the journal

Frontiers in Immunology

Received: 02 February 2020

Accepted: 06 April 2020

Published: 13 May 2020

Citation:

Wang L, Wang R, Xu C and Zhou H

(2020) Pathogenesis of Herpes

Stromal Keratitis: Immune

Inflammatory Response Mediated by

Inflammatory Regulators.

Front. Immunol. 11:766.

doi: 10.3389/fimmu.2020.00766
Herpes stromal keratitis (HSK) is one of the primary diseases that cause vision loss or even blindness after herpes simplex virus (HSV)-1 infection. HSK-associated vision impairment is predominantly due to corneal scarring and neovascularization caused by inflammation. In the infected cornea, HSV can activate innate and adaptive immune responses of host cells, which triggers a cascade of reactions that leads to the release of inflammatory cytokines, chemokines, microRNA, and other regulatory factors that have stimulating or inhibitory effects on tissue. Physiologically, host cells show homeostasis. In this review, we summarize the factors involved in HSK pathogenesis from the perspective of immunity, molecules, and pathological angiogenesis. We also describe in detail the pathogenesis of chronic inflammatory lesions of the corneal stroma in response to HSV-1 infection.

Keywords: stromal keratitis, immune response, herpes simplex virus (HSV-1), inflammation, pathogenesis

\section{INTRODUCTION}

Herpes simplex virus (HSV) mainly consists of HSV-1 and HSV-2, and the former is the primary pathogen of herpes stromal keratitis (HSK). HSV-1-induced corneal infection can cause a series of subsequent immune responses. HSK is currently considered a potentially blinding disease. The main clinical manifestations include corneal opacity, edema, corneal scarring, and neovascularization (NV), which can lead to irreversible vision impairment and blindness. HSV-1 in an infected cornea initiates virus replication in the corneal epithelial cells and binding of virus to Toll-like receptors (TLRs) on the cell surface that induces a cascade of innate immune responses and signal pathway responses, stimulating the production of inflammatory cells, cytokines, and chemokines that gradually infiltrate into the stroma. These inflammatory cells including neutrophils, dendritic cells (DCs), natural killer (NK) cells, and macrophages, reportedly help clear HSV-1 from the cornea during the initial infection (1). Importantly, NK cells limit viral replication via the production of type 1 interferons (IFNs) from corneal epithelial cells, resulting in enhanced antiviral activity (1). As antigen-presenting cells (APCs), DCs and macrophages can phagocytize viral particles and infected cells. Once the major histocompatibility complex II (MHC-II) transmits information presented by APCs to the surface of the helper T cells (e.g., Th1 and Th17 T cells), helper $\mathrm{T}$ cells are stimulated to produce cytokines and chemokines, eventually triggering adaptive immune responses that is a kind of delayed-type hypersensitivity (DTH) (Figure 1) (2). Th1 and Th17 $\mathrm{T}$ cells are two categories of $\mathrm{CD} 4^{+} \mathrm{T}$ cells, which are important in mediating the inflammatory immune response of HSK. 


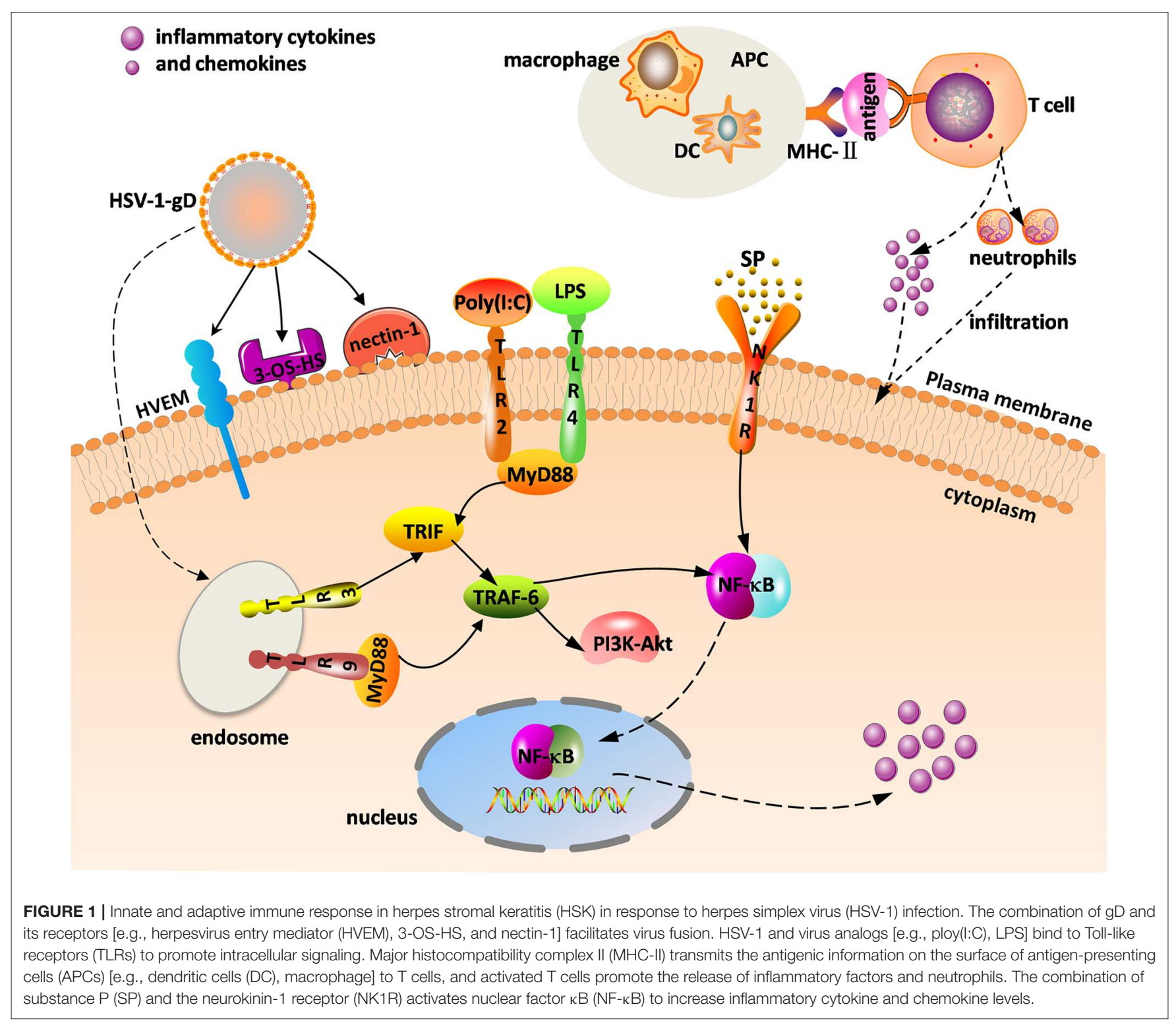

HSV-1 is a neurotrophic virus that is latent in the trigeminal ganglion (TG) following corneal primary infection. Reactivation of latent virus occurs in the context of hypoimmunity and autoimmune disorders. The virus travels back to the corneal epithelium along the axon, causing recurrent HSK. This chronic immune disease mediated by $\mathrm{T}$ lymphocytes is caused by viruses and corresponding antigens. In addition to cytokines and chemokines involved in HSK development, neuropeptide substance $\mathrm{P}$, glycoproteins, microRNAs, and other mediators participate in the pathological immune response of HSK. All of these regulators play dual roles of inhibiting and promoting disease during HSK pathogenesis. The purpose of this review is to provide a comprehensive overview of the pathogenesis and progression of HSK from different viewpoints including cellular immunity, inflammatory factors, and mediating molecules to better clarify the immunopathological process of HSK and provide an effective reference for its treatment.

\section{HSV-1 Entry Into Cells}

HSV-1 is a member of the alpha subfamily of herpesviruses and is a linear, double-stranded DNA virus surrounded by an icosahedral capsid. The capsid is composed of two layers of teguments: the inner one is composed of mRNAs and membrane proteins, and the outer tegument is covered by a lipid bilayer envelope containing various glycoproteins and membrane proteins (3). Glycoproteins encoded by the virus mainly include $\mathrm{gB}, \mathrm{gC}, \mathrm{gD}, \mathrm{gE}, \mathrm{gG}, \mathrm{gH}, \mathrm{gI}, \mathrm{gJ}, \mathrm{gK}, \mathrm{gL}, \mathrm{gM}$, and gN (4-6). For most herpesviruses, only four or five of these glycoproteins may be involved in viral cell entry. These representative glycoproteins mainly include $\mathrm{gB}, \mathrm{gC}, \mathrm{gD}, \mathrm{gH}$, and $\mathrm{gL}$, and their important role is to bind the virus to heparin sulfate (HS) on the cell surface (5). HS also simultaneously engages host receptors to gain HSV-1 entry into the cell.

HS is a glycosaminoglycan widely present on the cell surface and extracellular matrix (ECM) (7), which can interact with 
receptors and act as an attachment and receptor for HSV-1 to enter infected host cells $(5,8,9)$. HSV-1 binding to HS is the primary way to trigger virus entry. Depending on the different types of viral glycoprotein, there is a corresponding glycoprotein receptor on the cell surface. Taking gD as an example, the virus can fuse with host cells by combining $\mathrm{gD}$ with $\mathrm{gD}$ receptors, such as 3-OS-HS, herpesvirus entry mediator (HVEM), or nectin-1, which facilitates capsid penetration into the cytoplasm (Figure 1) (9). The capsid is then transported along microtubules to the nucleus, where viral DNA is released for virus gene replication and eventual production of viral progenies that can infect other nearby cells (9). Endocytosis is another pathway by which the virus accesses cells. An earlier study demonstrated that increased HS expression in the early stage of HSV-1 infection can promote virus attachment to cells. However, there is an unexpected decrease in HS later in the infection (10). We believe that decreased HS expression in this stage is mainly related to the HSdegrading enzyme heparanase (HPSE), which can clear HS from the surface of infected cells and further facilitate virus release (8). HPSE activation promotes viral egress from the corneal epithelium and contributes to HSK pathogenesis. Moreover, the virus can retrogradely transport from the corneal epithelium to the TG. This establishes latency, and reactivation of HSV-1 in the TG in some certain conditions results in recurrent HSK. Taken together, HSV entry, fusion, and egress are important conditions for HSK initiation.

\section{HSK Clinical Characteristics}

Stroma infection by HSV-1 is termed HSK, and the most serious clinical manifestation is a corneal ulcer. HSK is characterized by chronic inflammation of the corneal stroma, including cell infiltration, and NV. Recurrent HSK can result in long-term visual impairment due to the immune inflammatory response and is one of the leading causes of blindness.

Patients with HSK usually present with symptoms of redness, photophobia, tearing, eye pain, and blurred vision (11). Based on different clinical manifestations, HSK is divided into two clinical types: non-necrotizing stromal keratitis and necrotizing stromal keratitis. Non-necrotizing stromal keratitis, also known as immune stromal keratitis, is most common in patients with disciform keratitis. We can observe disc edema of the central corneal stromal without inflammatory cell infiltration and NV, as well as wrinkling of the Descemet membrane on slit lamp examination. Necrotizing stromal keratitis manifests as single or multiple yellow-white necrotic infiltrations in the corneal stroma. NV of the corneal stroma generally extends from the peripheral cornea to the infiltrating site of the central stroma. As the lesion progresses, necrotizing stromal keratitis can cause corneal thinning, ulceration, and even perforation. Overall, HSK is the result of an immune-mediated inflammatory response that leads to the development of corneal thinning, focal stromal opacity, corneal NV (CNV), corneal scarring, and potentially blindness (11).

\section{THE ROLE OF T CELLS IN HSK}

Studies in animal models of HSK have reported that $\mathrm{T}$ cells [e.g., $\mathrm{CD}^{+}{ }^{\mathrm{T}}$ cells, $\mathrm{CD} 8^{+} \mathrm{T}$ cells, and regulatory $\mathrm{T}$ cells (Treg)] are the principal orchestrators of immune pathological lesions, and these $\mathrm{T}$ cells play different roles and jointly promote HSK pathogenesis $(12,13)$. CD $4^{+} \mathrm{T}$ cells have a variety of phenotypes including helper and regulatory T cells (represented by Th1, Th2, Th17, etc.). $\mathrm{CD}^{+}$Th1 cells mainly secrete pro-inflammatory cytokines IFN- $\gamma$ and interleukin (IL)-2, which are primarily expressed in the early stage of HSK (14). Th2 cells produce protective cytokines IL-10 and IL-4 that are involved in the process of corneal repair. $\mathrm{CD}^{+}{ }^{+} \mathrm{T}$ cells appear on day 7 after HSV-1 infection and peak on day 10 post-infection (dpi) (15). HSK usually occurs $7 \mathrm{dpi}$ and peaks at 14-21 dpi (11). This indicates that the appearance of $\mathrm{CD} 4{ }^{+} \mathrm{T}$ cells is accompanied by clinical symptoms of HSK and adaptive immune responses. Within $24 \mathrm{~h}$ of infection, viral replication in the cornea triggers the innate immune response. Meanwhile, there is an influx of inflammatory cells including NK cells, DC, macrophages, and neutrophils, with neutrophils being the most important (11). Neutrophils account for $70-80 \%$ of leukocytes in the process of chronic inflammatory infiltration (16). There are two neutrophil chemotactic gradients in the immunopathological course of HSK. One appears when the virus replicates in the corneal epithelium. The other appears in the late stage of infection and is closely related to $\mathrm{CD}^{+}$and $\mathrm{CD}^{+}{ }^{+} \mathrm{T}$ cells that are essential for the establishment and maintenance of the second chemotactic gradient (17). Sherrie et al. demonstrated that increased levels of inflammatory cells such as neutrophils and DC generally infiltrate the cornea in the presence of activated $\mathrm{CD}^{+}$cells (18). It has been suggested that autophagic DCs are involved in the activation of $\mathrm{CD}^{+}{ }^{+} \mathrm{T}$ cells and play a catalytic role in the HSK immune response. In DC autophagy-deficient (atg $5^{\mathrm{fl} / \mathrm{fl}} \mathrm{CD} 11 \mathrm{c}$-cre) mice, both inflammatory cell infiltration and cytokine expression were decreased after the destruction of activated $\mathrm{CD}^{+}{ }^{+} \mathrm{T}$ cells, indicating that HSK severity decreased (19). The B and T lymphocyte attenuator (BTLA), a co-receptor expressed in $\mathrm{T}$ cells, can weaken the Th1 cell response by downregulating the number of $\mathrm{CD}^{+} \mathrm{T}$ cells, which impairs $\mathrm{DTH}$, thereby reducing the incidence of HSK lesions (15). CD4 ${ }^{+}$ cells are therefore important in promoting inflammatory cell secretion into the cornea and induce the immune inflammatory response. In a study of 12 HSK patients, virus-specific Tcell infiltration was found in the cornea, suggesting that the immunopathogenic T-cell response is directed to the initial virus but is not related to human corneal autoantigens, further demonstrating the importance of the T-cell immune response in HSK (20).

Researchers use C57BL/6 (HSV sensitive) and BALB/c (HSV resistant) mice with $\mathrm{CD} 4$ or $\mathrm{CD} 8$ gene knockout (KO) to test the roles of different $\mathrm{T}$ lymphocyte cell subsets in recurrent HSK. Their findings show that both $\mathrm{CD} 4^{+}$and $\mathrm{CD} 8^{+} \mathrm{T}$ cells contribute to stromal inflammation in HSK, depending on the host gene background (21). Inflammatory cell infiltration in the cornea of $\mathrm{CD} 4{ }^{+} \mathrm{T}$ cell-deficient mice peak at 14 days after HSV- 1 infection, and then gradually decrease until $35 \mathrm{dpi}$, indicating that $\mathrm{CD} 8^{+} \mathrm{T}$ cells may be involved in the inflammatory response and promote the infiltration of inflammatory cells dominated by neutrophils to the cornea in the absence of $\mathrm{CD} 4^{+} \mathrm{T}$ cells (22). In addition to the pro-inflammatory effect of $\mathrm{CD} 8^{+} \mathrm{T}$ cells, there is evidence that $\mathrm{CD}^{+}$tissue-resident memory $\mathrm{T}$ cells $\left(\mathrm{T}_{\mathrm{RM}}\right.$ cells), a subset 
of memory $\mathrm{CD}^{+} \mathrm{T}$ cells, have a protective effect and inhibit pathogen infection (23). Moreover, $\mathrm{CD}^{+} \mathrm{T}$ cells can be latent in the TG and suppress the virus reactivation there (24). To confirm this observation, the same research team used different test methods and came to the conclusion that this antigen-specific $\mathrm{CD} 8^{+} \mathrm{T}$-cell response in the TG did not enhance and maintain the latency; rather, $\mathrm{CD} 8 \alpha \mathrm{DCs}$ play a key role in establishment and maintenance of HSV-1 latency, thus reducing disease severity $(24,25)$. HSV-1 reactivation in the TG is a predominant cause of corneal blinding scarring (26). Similarly, HSV-1 infected the cornea of $\mathrm{CD}^{+}$and $\mathrm{CD} 8^{+}$T-cell-deficient mice, and $\mathrm{CD} 8^{+} \mathrm{T}$ cell-deficient mice showed more severe lesions than $\mathrm{CD} 4^{+} \mathrm{T}$-celldeficient mice, suggesting that $\mathrm{CD} 8^{+} \mathrm{T}$ cells have a protective effect against the immunopathological response of HSK (27). Compared with $\mathrm{CD}^{+} \mathrm{T}$ cells, the $\mathrm{CD} 8^{+} \mathrm{T}$-cell response is transient and plays a minor role in terms of the pro-inflammatory effect (28). This may be because $\mathrm{CD} 8^{+} \mathrm{T}$ cells are prominently latent in the infected TG and rarely present in the corneal stroma.

In addition, $\mathrm{CD}^{+}$Th17 cells can secrete the cytokine IL17 that induces neutrophil infiltration into the cornea and are mainly involved in the late stage of HSK, whereas Th1 cells predominate during the early stage (29). Tregs, another important subtype of $\mathrm{CD} 4^{+} \mathrm{T}$ cells in HSK pathogenesis, express transcription factor Foxp3, and DNA demethylation of Tregspecific demethylation region (TSDR) is the key to stable Foxp3 expression. Pro-inflammatory cytokines such as IL-2 and IL-6 can influence Treg stability by regulating the epigenetic status of the Foxp3 gene or its post-translational modification, which can lead to the production of ex-Tregs during HSK development. exTreg is a kind of Treg that once expressed Foxp3 but now lacks its expression. Under normal physiological conditions, there are no ex-Tregs in the cornea. In the inflammatory state, unstable Tregs can be transformed into ex-Tregs with the same pathogenicity as the effector $\mathrm{CD} 4^{+}$Th1 cells, thus aggravating the severity of HSK inflammatory lesions (12). The two most common types of Tregs are natural Tregs (nTregs) and induced Tregs (iTregs). nTreg comes from thymus and participates in preventing autoimmunity. Stabilized iTregs can effectively prevent the development of HSK lesions; they are generated from naive cells and induced in vitro (30). Tregs express IL-6R, and inhibition of the IL-6R signal pathway may contribute to Treg stability. IL-6 can induce the expression of DNMT1 (DNA methyltransferase 1) that methylates Foxp3, which directly downregulates Foxp3 gene expression. Azacytidine and retinoicacid enhance the suppressive function and stability of Tregs by inhibiting DNMT activity, which reduces HSV-1-induced corneal damage $(31,32)$. IL6 plays an important role in regulating the balance between Tregs and Th17 cells by promoting Th17 differentiation and inhibiting Treg differentiation (33). Moreover, $\mathrm{CD} 4{ }^{+} \mathrm{CD} 25^{+}$ Tregs can also protect the cornea from more severe lesions, and depletion of $\mathrm{CD} 4{ }^{+} \mathrm{CD} 25^{+}$Tregs can accelerate HSK progression (34). A recent study reported that treating the virus-induced inflammatory response with anti-IL-27 antibody can increase the numbers of $\mathrm{CD} 4^{+} \mathrm{Foxp}^{+}$Tregs, ameliorating tissue damage in the cornea (35). Collectively, Tregs play a protective role in maintaining homeostasis, enhancing immunological tolerance, and preventing autoimmune diseases. Tregs are regarded as protective immune regulatory mediators that can control the release of inflammatory cytokines and chemokines, as well as defend against viral invasion of the cornea (36).

\section{THE ROLE OF CYTOKINES IN HSK}

When HSV-1 infects the corneal epithelium, it spreads to the stroma or viral particles latent in the corneal stroma, and TG is activated, triggering the innate immune response followed by the adaptive immune response. This process induces the production of pro-inflammatory and anti-inflammatory cytokines. HSK occurs when the balance maintained by proinflammatory and anti-inflammatory mechanisms in vivo is shifted to an inflammatory state. The role of critical cytokines will be elaborated on from the perspectives of pro-inflammation and anti-inflammation.

\section{Regulation of HSK by Pro-inflammatory Cytokines}

IL-17 is responsible for the immune-inflammatory response of HSK; this crucial pro-inflammatory cytokine can stimulate the production of pro-inflammatory cytokines and neutrophil chemotactic factors by regulating the secretion of corneal stromal fibroblasts (37). To date, IL-17 family members have been identified, including IL-17A to IL-17F, of which IL-17A is the most familiar one and can be detected in corneal epithelium (38). Treatment of an HSK mice model with an anti-IL17 antibody can effectively suppress the DTH response and significantly reduce lesion severity (39). Xia et al. speculated that the pro-inflammatory mechanism of IL-17 may be promoting the DTH response and upregulating tumor necrosis factor (TNF)$\alpha$ expression (39). IFN- $\gamma$ is one of the factors regulating IL-17 expression in the cornea. IFN- $\gamma$ can activate the innate immune system, leading to increased secretion of various cytokines, and chemokines. Molesworth-Kenyon and colleagues reported that high expression of IL-17 occurs in the cornea of IFN- $\gamma$ KO mice, indicating that IFN- $\gamma$ negatively regulates IL-17 expression (40). They performed reverse transcription polymerase chain reaction (RT-PCR) and found that IL-17 mRNA is increased within $24 \mathrm{~h}$ after HSV-1 infection and subsequently remains at a lower level during 7 dpi (40). However, Suryawanshi et al. observed that there were two waves of IL-17: the first peak was 2 dpi and the second gradually increased during 7-21 dpi (29). It can be concluded that IL-17 is involved in the whole immune response of HSK, again emphasizing the importance of IL-17. Previous RTPCR studies showed IL-17R in corneal fibroblasts in the human cornea. Binding of IL-17 to TNF- $\alpha$ or IFN- $\gamma$ can promote the production of IL-6, IL-8, and macrophage inflammatory protein 3 (MIP3)- $\alpha$, which accelerates the development of inflammation in HSK (37).

TNF- $\alpha$ is a pro-inflammatory cytokine produced mainly by Thl cells as well as by macrophages (41). IL-1 and TNF- $\alpha$ jointly promote the occurrence of the inflammatory lesions in recurrent HSK, and TNF- $\alpha$ can indirectly advance the properties of IL-1 (42). Contrary to our previous view, Minagawa et al. reported that TNF- $\alpha$ plays an antiviral role in primary and 
recurrent acute HSV-1 infection (43). IL-1 is expressed in the HSV-1-infected corneal epithelium, which can synergistically promote the infiltration of polymorphonuclear leukocytes into the cornea together with IL-6, triggering a series of inflammatory cascade reactions and inducing HSK (44). IL-6 is a critical pro-inflammatory cytokine that can significantly increase the chemokines MIP- $1 \alpha$ and MIP-2, thereby recruiting neutrophils to infiltrate the infected cornea (45). After corneal infection with HSV-1, IL-17, together with TNF- $\alpha$, can increase the secretion of IL-6, which is involved in the immunopathology, and NV of HSK (37). Consistent with the above experimental results, Hou et al. found that IL-17F could upregulate IL-6 levels and plays a major role in the earlier acute stage of HSK (46). Others observed that drug treatment of HSV-1-induced HSK can significantly reduce IL-6 levels in the mouse cornea (47). Nevertheless, under certain circumstances, IL-6 is considered to be an anti-inflammatory cytokine (48). More interestingly, IL-6 is not an essential cytokine for recurrent HSK (49). In addition to its role as a pro-inflammatory cytokine, IL-6 is also involved in $\mathrm{CNV}$ formation, which will be detailed in the following sections.

\section{Regulation of Anti-inflammatory Cytokines in HSK}

In addition to the minor effect mentioned above, IFN $-\gamma$ produced by NK and Th1 cells plays a protective role in HSK pathogenesis (50). IFN- $\gamma$ is also known as a Th1-derived cytokine and regulates the neutrophil invasion into the cornea. IFN- $\gamma$ is generally detected on $3 \mathrm{dpi}$ in the inflamed sites of corneal stroma and lasts until $12 \mathrm{dpi}$ (51). The treatment of HSK with antisense oligonucleotides targeting IFN- $\gamma$ mRNA (IFN- $\gamma$-ASON) in vitro and in vivo obviously improves the incidence of HSK (52). However, another study demonstrated that IFN- $\gamma$ has a dual role in the HSV-1-induced immune response. IFN- $\gamma$ plays a protective role in the early stage of HSK due to inhibition of the production of Th17 cells and limiting viral replication in the cornea, but IFN- $\gamma$ accelerates the immunopathological process in the late stage in coordination with Th17 cells (29). Additionally, both IFN- $\gamma$ and TNF- $\alpha$ are protective after HSV-1 infection and inhibit reactivation in latency, as shown using IFN- $\gamma$ and a TNF$\alpha$ KO mouse model (53). More importantly, IFN $-\gamma$ can maintain the latency of the virus in the TG, effectively inactivating it (54). IFN- $\gamma$ can prevent viral replication in primary and recurrent HSK and reduce the incidence of corneal edema. Compared with mice with primary HSK, the IFN- $\gamma$ KO mice showed more severe clinical manifestations in recurrent HSK (55). This shows that IFN- $\gamma$ exerts both antiviral and pro-inflammatory effects in different stages of recurrent HSK (56). IFN- $\alpha / \beta$ is classified as type I IFN that can trigger a variety of antiviral pathways in vivo (e.g., RNase L, PKR) and also maintain the maturation and activation of DCs and T lymphocytes (57). IFN- $\alpha / \beta$ can control HSV-1 replication and reactivation of the virus in the TG during acute ocular infection, thus controlling the transmission of the virus from the TG to the cornea (57). IFN- $\gamma$ and IFN- $\beta$ can synergistically dampen virus replication in vivo and in vitro, which results in enhancing antiviral effects and resisting viral infection (58).
Studies in mouse models of HSK have revealed that Tregs and IL-10 independently play protective roles in the HSV-1induced inflammatory response. Depletion of IL-10 and/or Tregs can potentiate the severity of the HSV-1 infection in the cornea. One anti-inflammatory mechanism of IL-10 is to suppress the proliferation of $\mathrm{CD}^{+}$and $\mathrm{CD}^{+} \mathrm{T}$ cells and the production of inflammatory cytokines and chemokines such as IL-2, IL6 , and MIP- $1 \alpha(59,60)$. The other mechanism is that IL-10 can inhibit the DTH response (61). Based on the reduction of infiltration of neutrophils into the cornea by IL-10 treatment, we can conclude that IL-10 can significantly reduce the incidence of HSK $(60,61)$. IL-10 is derived from corneal epithelium cells and fibroblasts and is an endogenous immunosuppressive cytokine $(62,63)$. Some researchers have proposed treating HSK by upregulating IL-10 (64). To date, we are familiar with two major anti-inflammatory cytokines: IL-10 and IL-4. IL-4 is also known to downregulate inflammatory cytokine expression and protect against HSV-1-induced corneal scarring. More importantly, IL-4 can reduce viral replication in the cornea $(65,66)$. IL-4 can also promote immune responses in the context of allergy or parasitic infections. Overall, pro-inflammatory and anti-inflammatory cytokines maintain a balance during HSK pathogenesis. Both pro-inflammatory and anti-inflammatory effects depend on the particular condition, and some cytokines may have dual roles. There are more inflammatory cytokines that need to be identified to better understand their role in HSK pathogenesis.

\section{THE ROLE OF CHEMOKINES IN HSK}

Chemokines have chemotactic specificity and can recruit neutrophils to gather at the site of lesions, leading to the development of diseases. These chemokines are thought to have pro-inflammatory properties. In contrast, some chemokines are homeostatic and can control disease progress (67). Chemokines bind to $G$ protein-coupled receptors, which induce conformational changes, thereby activating intracellular signal transduction pathways and triggering the inflammatory response. Most chemokines have conserved cysteines in amino acid sequences. According to the difference of the first two cysteine locations, chemokines can be divided into four families: CXC, CC, $\mathrm{C}$, and CX3C. The two major chemokine types are CXC and CC (68). A variety of chemokines are involved in the pathology process of HSK, including CCL2, CCL3, CXCL1, and CXCL10.

CXCL1, also known as keratinocyte-derived chemokine (KC), is the only chemokine produced by the central corneal epithelium and is considered a neutrophil chemoattractant (69). CXCL1 contributes to neutrophil migration to the cornea early after infection, especially on 3 dpi. Bryant-Hudson et al. further demonstrated that CXCL1 and CXCL2 are not involved in clearing the virus (70). The recurrence rate in the anti-CXCL1 treatment group was significantly lower than the other two groups in a mouse model of recurrent HSK, indicating that CXCL1 is essential to recurrent HSK (49).

CXCL10 has a protective function and is homeostatic, and this unique chemokine is expressed in the TG and epithelial cells. The 
receptor of CXCL10 is CXCR3, and it participates in the Th1 response (67). Based on the research of Srivastava and colleagues, we speculate that CXCL10 can control the inflammatory response via two ways: (1) involvement in the immunity of antiviral $\mathrm{CD} 8^{+}$ $\mathrm{T}$ cells in the infected cornea and TG and (2) elevating the level of protective HSV-specific $\mathrm{CD} 8^{+} \mathrm{T}$ cells in infected tissues. As a result, mice lacking CXCL10/CXCR3 have shown more severe lesions (71). Previous studies also demonstrated that the absence of CXCL10 increases the influx of inflammatory cells to infected corneas and the expression of angiogenic factors, which exacerbates HSK severity (72). Additionally, Srivastava et al. reported that boosting the number and function of HSVspecific CD8 ${ }^{+} \mathrm{T}$ cells by CXCL10 in the cornea and TG can protect the cornea against HSV-1 infection (73). In line with these results, enhancing CXCL10 levels can bolster the number of effector memory $\mathrm{CD} 8^{+} \mathrm{T}$ cells $\left(\mathrm{T}_{\mathrm{EM}}\right)$ and tissue-resident memory $\mathrm{CD}^{+} \mathrm{T}$ cells $\left(\mathrm{T}_{\mathrm{RM}}\right)$ in the $\mathrm{TG}$, to inhibit viral reactivation and reduce the incidence of recurrent HSK (74). However, it is interesting that lack of CXCL10 weakens the severity of HSK and that CXCL9 was detected in the absence of CXCL10, indicating that CXCL10 has dual pro-inflammatory and anti-inflammatory roles, and CXCL9 accelerates HSK progression (75).

CXCL9 comes from resident corneal cells and neutrophils and can aggregate neutrophils and trigger an inflammatory response (76). The presence of TLR9 and type IIFN signaling is a precondition for CXCL9 and CXCL10 expression in the cornea following HSV-1 infection (77). The pro-inflammatory role of CXCL9 is associated with T-cell trafficking into the cornea, as decreased infiltration of $\mathrm{CD} 4^{+} \mathrm{T}$ cells is found in the mice lacking CXCL9 (78). Conversely, chemokine levels should be reduced in vivo in the absence of $\mathrm{CD} 4^{+} \mathrm{T}$ cells post HSV-1 infection, while the number of CXCL9 and CCL5 are not reduced significantly after $3 \mathrm{dpi}$ in the context of $\mathrm{CD} 4^{+} \mathrm{T}$-cell depletion (79). CXCL9 and CXCL10 bind to the same receptor CXCR3. Mice deficient in CXCR3 and CXCR5 manifest less severe diseases, indicating that both receptors play crucial functions in the pathological immune response to HSK (80).

CCL2, also known as monocyte chemoattractant protein (MCP-1), is a critical mediator of inflammatory monocyte recruitment into the cornea (81). The corneal stromal cell is the primary source of MCP- 1 and CCL5, which in turn elicits CD4 ${ }^{+}$ T-cell migration toward corneal lesions, exacerbating stromal inflammation (82). Moreover, CCL2 production is driven by IFN- $\alpha$, which recruits inflammatory cells to infected sites to induce inflammatory responses (81). Nevertheless, the results of a previous study demonstrated that MCP-1 is not the major inflammatory chemokine in the HSV-1-infected cornea. Decreased macrophage infiltration was observed in MCP-1 $\mathrm{KO}$ mice, but overexpression of pro-inflammatory cytokines and other chemokines (e.g., MIP-2/CXCL2 and MIP-1 $\alpha$ ) was associated with more severe lesions and angiogenesis, suggesting that MIP-2 plays an important role in the absence of MCP-1 (83).

MIP- $1 \alpha / C C L 3$ is another regulator of C-C chemokines that functions as a protective chemokine by protecting against viral infection in the cornea (84). MIP-2 and MIP- $1 \alpha$ are generated following the stimulation by IL-17, which is further proof for the pro-inflammatory role of IL-17 in HSK pathogenesis (40).
However, an earlier study had reported that MIP-2 and MIP$1 \alpha$ were pivotal promoters of neutrophil influx into the corneal infection site (40). From the perspective of the response of MIP$1 \alpha$ to inflammatory cells, it can be concluded that MIP- $1 \alpha$ also has a dual function of promoting and inhibiting the development of HSK. CCL5 was also detected in the HSV-1-infected cornea where it binds to the receptor CCR5 to mobilize neutrophil migration to the cornea (85). In conclusion, the expression of chemokines in the HSV-1-infected cornea largely influences inflammatory cell infiltration into the cornea.

\section{THE ROLE OF GLYCOPROTEINS IN HSK}

Glycoprotein $\mathrm{K}(\mathrm{gK})$ is one of the 12 known glycoproteins encoded by the virus, and HSV-1 is covered by glycoproteins. $\mathrm{gK}$ is mainly involved in viral entry into corneal epithelial cells, membrane fusion, the intracellular spread of virions, and virion egress (86). Many studies support the viewpoint that $\mathrm{gK}$ plays important roles in viral replication and corneal scarring $(6,87)$. Lack of $\mathrm{gK}$ can reduce virus transmission to the corneal epithelium and TG, which prevents the establishment of latency and thus inhibits viral replication and reduces the development of corneal nerve damage $(88,89)$. The cause of corneal neuroinvasiveness appears to be the amino terminus of gK (90). Researchers investigated the effect of HSV-1 infection in the mouse cornea by overexpressing $\mathrm{gK}$. They found that overexpression of gK increased the severity of corneal scarring by altering how the virus bound to the receptor by modulating the expression of HSV-1 receptors, such as 3-OS-HS, HVEM, and nectin-1 or nectin-2 (91). One hypothesis is that binding of gK to signal peptide peptidase (SPP) exacerbates corneal scarring and leads to blindness $(87,92)$. The pathogenicity of this combination is mainly manifested as increased viral replication and the establishment of latency, as well as enhanced numbers of viral transcripts in the cornea and TG (87). Furthermore, we have realized that $\mathrm{gK}$ is the only glycoprotein that binds SPP in vitro (92), and recent research further demonstrated that the combination of gK and SPP can occur in vivo (87). Therefore, the importance of $\mathrm{gK}$ in the pathogenesis of HSK is compelling.

It was also found that $\mathrm{CD} 8^{+} \mathrm{T}$ cells, usually considered as $\mathrm{CD}^{+}{ }^{+} \mathrm{CD} 25^{+} \mathrm{T}$ cells, play a decisive role in accelerating corneal scarring in gK-immunized mice $(6,93)$. A particular peptide is $\mathrm{gK}$ T-cell-stimulatory region as well as $\mathrm{CD}^{+}{ }^{\mathrm{T}}$ cell epitope, which is named $\mathrm{gK} 8 \mathrm{mer}$. We conclude that $\mathrm{gK}$ 8 mer participates in accelerating corneal scarring by inducing the $\mathrm{CD}^{+}$T-cell response $(94,95)$. Reducing of the level of $\mathrm{CD} 8^{+} \mathrm{T}$-cell infiltration in the cornea of gK-immunized mice can attenuate corneal scarring (96). Additionally, the property of antibody-dependent enhancement (ADE) of gK contributes to potentiating HSV-1 infection in corneal stroma compared with glycoprotein $\mathrm{D}(\mathrm{gD})$ (97), so $\mathrm{gD}$ plays a protective role in HSK.

Researchers extracted corneal HSV-1 isolates from 178 HSK patients for genetic testing of gG, gI, and gE. There was a high glycoprotein detection rate in HSV-1 isolates, but the clinical manifestation of HSK was independent of gG or gI genotype (98). 
Similarly, a case report on HSV-1-induced keratitis described a significant finding that gG and gI were detected in tear samples from patients with bilateral necrotizing herpes simplex keratitis (99). Unfortunately, the correlation between HSV-1 genotype and clinical manifestations is not very clear. In a word, antibody titers such as $\mathrm{gB}, \mathrm{gD}, \mathrm{gK}$, and $\mathrm{gE}$ can be detected in the sera of patients with HSK, and $\mathrm{gD}$ and $\mathrm{gK}$ are the most widely studied. The mechanisms by which gK exacerbates HSK can be summarized as follows: (1) the combination of gK and SPP, (2) the $\mathrm{CD}^{+}{ }^{+} \mathrm{T}$-cell response induced by $\mathrm{gK}$, (3) the involvement of $\mathrm{gK}$ in axonal transport, and (4) the expression of receptors regulated by $\mathrm{gK}$. Blocking any of the above gK-induced processes can reduce HSK severity and inhibit viral replication. Thus, $\mathrm{gK}$ is an important determinant in viral infectivity and corneal manifestation in HSK.

\section{THE ROLE OF SUBSTANCE P IN HSK}

Substance P (SP) is a neuropeptide substance produced by nerve fibers and APCs in the corneal stroma during the clinical phase. $\mathrm{SP}$ is a pro-inflammatory mediator involved in stimulating the production of inflammatory cytokines and chemokines (100). Intraperitoneal injection of SP increases inflammatory cell levels in mice, leading to more severe diseases (101). The level of SP in the HSV-1-infected corneal stroma is in direct proportion to HSK severity. With higher amounts of SP, more inflammatory cells and $\mathrm{CD}^{+} \mathrm{T}$ cells are produced (100). The reason for this pro-inflammatory effect is that the binding of SP to the neurokinin-1 receptor (NK1R) activates the nuclear factor- $\kappa \mathrm{B}$ $(\mathrm{NF}-\mathrm{k}$ ) signal pathway, triggering neutrophil influx into the inflamed cornea (102). NK1R is an important receptor of SP and is expressed in corneal epithelium. The affinity of SP and NK1R determines the rate of HSK progression. In the early stage of infection, the corneal opacity and angiogenesis of HSK are aggravated in mice lacking in NK1R, which is contrary to the previous view that absence of NK1R can reduce the severity of eye diseases (103). The number of sloughing of apical corneal epithelial cells and viral load increase after HSV1 infection, and $\mathrm{CD} 4^{+} \mathrm{T}$ cells are upregulated, which promotes the infiltration of inflammatory cytokines and chemokines, such as MIP-2, MIP-1 $\alpha$, and MCP-1 (103). Studies have revealed that increased release of chemokine and chemokine receptors is due to binding of SP to NK1R and subsequent activation of the NF- $\kappa$ B pathway (104). Moreover, with the exception of pro-inflammatory properties, SP is also involved in wound healing. Activation of the PI3K/Rac1/RhoA pathway following SP binding with NK1R can promote keratocyte migration, which promotes stromal wound repair. SP also stimulates keratocytes to produce IL-8, which further contributes to keratocyte migration and leads to an acute inflammatory response (105). SP also plays a role in promoting corneal angiogenesis in humans and mice (106). NK1R antagonists can significantly reduce the extent of $\mathrm{CNV}$ in both alkali burn and suture-induced NV models and downregulate SP levels (107). Collectively, SP promotes HSK pathogenesis by expanding the effects of proinflammatory responses.

\section{THE ROLE OF microRNAs IN HSK}

microRNAs (miRNAs) are small, single-stranded, non-coding RNAs that promote mRNA degradation or inhibit protein expression by regulating gene expression (108). miRNAs play crucial roles in viral latency, viral replication, inflammation, and CNV in HSK $(108,109)$. The involved miRNAs have been reported as miR-155, miR-132, miR-183, miR-23b, miR-326, miR-21, and miR-H2, etc. (108). Of these, miR-155 and miR-132 are the most studied widely in HSV-1-induced corneal infection.

HSV-1 infection of the cornea induces the production of inflammatory cells and SP and also upregulates the level of miR155 , which can lead to overexpression of inflammatory cytokines and chemokines as well as augmented Th1 and Th17 immune responses that contribute to more severe corneal opacity and angiogenesis (110). miR-155 expressed in activated CD ${ }^{+} \mathrm{T}$ cells suppresses the levels of phosphatidylinositol-3,4,5-trisphosphate 5 -phosphatase 1 (Ship1) and IFN- $\gamma$ receptor $\alpha$-chain (IFN- $\gamma$ R $\alpha$ ), and viral replication is not associated with the induction of increased miR-155 (110). Based on this, we propose that miR-155 influences corneal damage via different pathogenic ways and has a prominent role in HSK pathology. Increased expression of miR132 is detected after HSV-1 infection, and miR-132 promotes CNV (111). It also enhances viral replication by suppression of the p300 transcriptional co-activator, directly regulating the innate immune response (112). In terms of HSK, miR-H2 is mainly expressed in the TG, which can reduce viral latency, and prevent virus reactivation by dampening expression of the ICP0 gene. Conversely, the miR-H2 mutation can increase the activation rate of viral latency and accelerate HSK progression. Therefore, miR-H2 plays a role in attenuating lesion formation during HSK pathogenesis (113). This review lists the typical miRNAs involved in HSK; it is of great significance to target the inflammatory miRNAs to treat this (Table 1).

\section{CNV FORMATION}

$\mathrm{CNV}$ is a serious clinical manifestation in the advanced stage of HSK and is one of the leading causes of blindness. The cornea, itself, is a transparent, avascular tissue. When the host cornea is infected by HSV-1, neutrophils are stimulated to migrate to the stroma. Under hypoxic conditions, vascular endothelial cells and pericytes are destroyed, and the level of vascular endothelial growth factor (VEGF) is subsequently upregulated and binds with the soluble VEGF receptor (sVEGFR1). However, upregulation of VEGF-A suppresses sVEGFR-1 expression, which influences binding of VEGF-A and sVEGFR1 and further promotes the formation of new vasculature (116). VEGF includes four subtypes: VEGF-A, VEGF-B, VEGF-C, and VEGF-D. Among these, VEGF-A is the most prominent in the formation of new blood vessels (117) and is mainly derived from neutrophils in the late stage of HSK (118). The basic steps of CNV formation include $(116,117)$ : (1) leukocyte accumulation at lesions, (2) destruction of the basement membrane of corneal endothelial cells and ECM degradation (3), endothelial cell proliferation, and (4) the formation of new vascular sprouts and lumens. Multiple inflammatory mediators are involved in the 
TABLE 1 | Role of microRNAs in herpes stromal keratitis (HSK) $(108,109,114,115)$.

\begin{tabular}{|c|c|c|c|}
\hline miRNA & Targets & Function & Effects \\
\hline HSV-1-miR-H6 & ICP4 & Maintains and establishes HSV-1 latency & Anti-inflammation \\
\hline HSV-1-miR-H2 & ICPO & $\begin{array}{l}\text { Decreases neurovirulence and reactivation, promotes } \\
\text { HSV-1 latency }\end{array}$ & Anti-inflammation \\
\hline miR-649 & MALT1 & Promotes HSV-1 replication & Pro-inflammation \\
\hline miR-101 & GRSF1/ATP5 $\beta$ & Inhibits HSV-1 replication & Anti-inflammation \\
\hline miR-23a & IRF1 & Promotes HSV-1 replication & Pro-inflammation \\
\hline \multirow[t]{2}{*}{ miR-23b } & $\mathrm{NF}-\kappa \mathrm{B}$ & Inhibits NF-кB expression & Anti-inflammation \\
\hline & TAB2, TAB3, IKK- $\alpha$ & $\begin{array}{l}\text { Inhibits IL-17-associated immune inflammatory } \\
\text { expression }\end{array}$ & \\
\hline miR-138 & ICPO & Promotes host survival and viral latency & Anti-inflammation \\
\hline miR-155 & Ship1/IFN $\gamma-R \alpha$ & $\begin{array}{l}\text { Promotes CD4 }{ }^{+} \text {T-cell proliferation, promotes Th1 and } \\
\text { Th17 cell immune response }\end{array}$ & Pro-inflammation \\
\hline \multirow[t]{2}{*}{ miR-132 } & Ras-GAP & Promotes VEGF signaling & Pro-angiogenesis \\
\hline & $\begin{array}{l}\text { p300 transcriptional } \\
\text { co-activator }\end{array}$ & Promotes viral replication & Pro-inflammation \\
\hline \multirow[t]{2}{*}{ miR-21 } & - & Induces IL-10 production & Anti-inflammation \\
\hline & Sprouty $2 / 4$ & Inhibits VEGF-A and HIF-1 $\alpha$ expression & Anti-angiogenesis \\
\hline miR-146a & - & $\begin{array}{l}\text { Inhibits NF-кB and TLR activation, inhibits cytokine } \\
\text { production, regulates Tregs to control Th1 response }\end{array}$ & Anti-inflammation \\
\hline miR-219 & 5-Lipoxygenase & Increases SPM* production & Anti-inflammation \\
\hline miR-208a & - & Induces IL-10 production & Anti-inflammation \\
\hline miR-146b & - & Negatively regulates IL-8/RANTES & Anti-inflammation \\
\hline miR-855,miR-491, miR-212 & - & Negatively regulates MMP9 & Pro-angiogenesis \\
\hline miR-29 & Tbet/Eome & Promotes IFN- $\gamma$ production by Th1 cells & Pro-inflammation \\
\hline miR-326, miR-301a & - & Th17 cell production & Pro-inflammation \\
\hline miR-292-2 & Lipoxygenase & Reduces leukotrienes and induces SPM production & Anti-inflammation \\
\hline miR-10a & Tregs & Stabilizes Tregs & Anti-inflammation \\
\hline miR-182 & Foxo1 & Promotes T-cell proliferation & Pro-inflammation \\
\hline $\operatorname{miR}-31$ & $\mathrm{FIH}-1$ & Promotes keratocyte glycogen metabolism & Pro-angiogenesis \\
\hline miR-27a & Sema7A & Enhances VEGF-A levels & Pro-angiogenesis \\
\hline miR-145 & ITGB8 & Regulates human corneal epithelial differentiation & Anti-angiogenesis \\
\hline \multirow[t]{2}{*}{ miR-184 } & miR-205 & Maintains SHIP2 levels in epithelia & Anti-angiogenesis \\
\hline & VEGF & Inhibits VEGF expression & \\
\hline miR-204 & VEGF, VEGFR2 & Reduces VEGF and VEGFR2 expression & Anti-angiogenesis \\
\hline
\end{tabular}

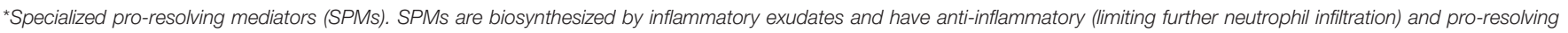
(enhancing macrophage clearance of microbial peptides and apoptotic cells) actions.

process of CNV, including pro-angiogenic factors IL-6, IL-10, IL17A, CXCL10, miR-132, matrix metalloproteinases (MMPs), and others (119). NV is usually induced when there is an imbalance between pro-angiogenic factors and sVEGFR-1.

HSV-1 infection initiates innate and adaptive immune responses followed by a cascade of inflammatory cytokines, for example, IL-17 production. IL-17A, a member of the IL17 family, directly induces increased VEGF-A production after viral infection, and indirectly promotes the synthesis of VEGF-A with IL-6 (120). MMP production (MMP-2, MMP-7, and MMP9) is simultaneously upregulated, which can degrade sVEGFR1 as well as the ECM, further exacerbating vascular leakage (120). In terms of promoting angiogenesis, IL-17 acts on the cornea as well as on other ocular diseases, such as proliferative diabetic retinopathy and age-related macular degeneration (121, 122). Reducing IL-17 can decrease the severity of CNV. VEGF secretion is induced by stimulating corneal epithelial cells and stromal fibroblast cells with IL-6 post-HSV-1 infection, leading to $\mathrm{CNV}$. As the concentration of IL-6 increases, so does that of VEGF (123). Moreover, CXCR2 is a receptor for pro-inflammatory chemokines and is involved in neutrophil recruitment. The absence of CXCR2 prevents the chemokines from binding to it, which can theoretically reduce neutrophil infiltration and alleviate the severity of corneal damage. However, an interesting study on IL-6 promoting angiogenesis showed exacerbation of HSK in CXCR2 KO mice, mainly manifested as CNV, which is related to increased IL-6 (124). Therefore, IL-6 has both pro-inflammation and pro-angiogenesis roles (125) in HSK pathogenesis. Fibroblast growth factor- 2 exerts a stronger and more persistent influence on HSV-1-induced CNV compared with IL-6 (125). As mentioned above, the gene regulator miR-132, as a gene regulator, plays a critical pro-angiogenic role in $\mathrm{CNV}$. 
Treatment with nanoparticles loaded with miR-132 antagonists can effectively decrease the extent of CNV and diminish corneal edema in HSK (111). Multiple of miRNAs have been implicated in CNV (115), from which we can infer that they have a crucial role in HSK pathogenesis.

Conversely, the cytokine IL-10 suppresses $\mathrm{CNV}$, and treatment of recurrent HSK with IL-10 can attenuate the severity of angiogenesis $(61,63)$. Likewise, blockade of CXCL10 expression exacerbates angiogenesis in HSK (72). IL-18 inhibits $\mathrm{CNV}$ by dampening endothelial cell proliferation, leading to decreased expression of VEGF (126). As such, MMPs mainly including MMP-2 and MMP-9 increase after HSV-1 infection, which plays a catalyst role in NV. In the early stage of viral infection, MMP-9 production is stimulated by inflammatory cells, especially neutrophils, and depletion of neutrophils can reduce MMP-9 activation (127). Both MMP-2 and MMP-9 can degrade the ECM and release pro-angiogenic factors, and the main components of vascular basement membranes are MMP-2 and MMP-9, so both of them are considered as the proteolytic enzymes to degrade the basement membrane, which confirm that MMPs promote CNV (117). MMPs degrade sVEGFR-1, which further contributes to the development of CNV (118). It has also been reported that MMP alone does not promote the formation of new blood vessels (125). Moreover, endothelial receptor Robo4 (R4) can control angiogenesis, and subconjunctival injection of soluble $\mathrm{R} 4$ into wild-type mice significantly diminishes the extent of CNV because R4 activates the anti-angiogenic pathway (128). In summary, an imbalance between pro-angiogenic and anti-angiogenic factors results in excessive VEGF, enhancing the development of CNV. Also, CNV occurs when the cornea is exposed to inflammation, hypoxia, and limbal stem cell deficiency (116). If pro-angiogenic factors are effectively controlled during the NV stage, it could reduce the blinding rate of HSK.

\section{OTHER MECHANISMS}

\section{Regulation of HSK by Signaling Pathways}

Polyinosinic-polycytidylic acid [poly(I:C)] is a synthetic analog of viral double-stranded RNA that induces the expression of adherence molecules in corneal fibroblasts by activating multiple signaling pathways including mitogen-activated protein kinase (MAPK), phosphoinositide 3-kinase (PI3K)-Akt, and NF-кB. Of these, NF- $\kappa \mathrm{B}$ is the primary signal pathway, and it is downstream of the PI3K pathway (129). NF- $\kappa \mathrm{B}$ is a critical transcriptional regulatory factor that regulates the expression of various factors such as cytokines and adherence molecules that influence host immune responses. As a regulator in the signal pathway, NF$\kappa \mathrm{B}$ plays an important role in the immunopathology of HSK. Adherence molecules, including intercellular adhesion molecule1 and vascular cell adhesion molecule-1, bind to cytokines, and chemokines to induce inflammatory responses. Poly(I:C) also increases TLR3 expression in corneal fibroblasts, which is recognized by the virus and further binds with it, leading to innate immune responses and enhanced secretion of cytokines and chemokines (130, 131). Moreover, poly(I:C) induces the activation of MAPKs, including extracellular signal-regulated kinase, p38, and c-Jun NH2-terminal kinase, all of which mediate the expression of inflammatory cells and adhesion molecules (130). Based on a full understanding of the role of signal pathways in HSK pathogenesis, researchers usually consider each signal pathway as a treatment target, looking for more appropriate drugs to inhibit the inflammatory response. As an example, $\mathrm{H}$ $\mathrm{RN}$ is an 11-amino-acid peptide that can suppress the activation of NF- $\kappa \mathrm{B}$ and MAPK signal pathway, thereby subsequently diminishing the production of pro-inflammatory cells that are involved in HSK induced by poly(I:C) and lipopolysaccharide (LPS) (132).

\section{Herpesvirus Entry Mediator}

Herpesvirus entry mediator (HVEM) is a member of the TNF receptor superfamily that interacts with corresponding ligands, such as immunoglobulin (Ig), TNF, and gD; it is important for viral entry, fusion, and ultimately $\mathrm{HSV}-1$ pathogenesis. The Ig ligands of HVEM include BTLA and CD160, and TNF ligands include LIGHT and lymphotoxin- $\alpha$ (LT- $\alpha)$ (133-135). HVEM is expressed on a variety of cell surfaces, including $\mathrm{T}$ cells, B cells, macrophages, and DCs (136). Binding of HVEM to $\mathrm{gD}$ contributes to capsid release into the cytoplasm, then the capsids transported to the nucleus where viral replication occurs $(9,137)$. As a TNF receptor, HVEM can combine with LIGHT to promote the release of TNF receptor-associated factors to the cytoplasm, thus activating the NF- $\mathrm{B}$ signaling and enhancing the production of cytokines and other related factors and initiating immune inflammatory responses (136). Meanwhile, HVEM-mediated NF- $\kappa \mathrm{B}$ activation could also improve the survival of neuron reactivation. CD160 is detected on CD4 ${ }^{+}$ and $\mathrm{CD}^{+} \mathrm{T}$ cells. The interactions of CD160 and BTLA with HVEM inhibit CD4 ${ }^{+}$T-cell activation, whereas it is enhanced by binding of HVEM and LIGHT (135). CD4 ${ }^{+}$T-cell activation triggers the T-cell immune response. Previous studies have demonstrated that HVEM is a pro-inflammatory factor that is a determinate of HSV-1-induced corneal infection pathogenesis (138). Compared with the controls, viral replication and severe symptoms are not observed in HVEM KO mice, and cytokine levels are decreased after HSV-1 infection (138, 139). It is also thought that HVEM in corneal epithelial cells suppresses the production of cytokines and chemokines in response to HSV-1 infection (140). Whether HVEM is pro-inflammatory or anti-inflammatory depends on the interactions with various cell types with different ligands that bind to it. Given that the entry interaction between HVEM and gD does not influence the corneal clinical symptoms, the pathogenic role of HVEM in HSK could be due to its immunomodulatory function in the inflammatory immune process (139). HVEM also contributes to HSV-1 latency in the TG. Latency-associated transcript is a viral gene that is continuously expressed during latency; it promotes HSV-1 reactivation and the establishment of latency by upregulating HVEM expression. HSV-1 latency was significantly decreased in HVEM KO mice, indicating that HVEM plays an important role in this process (141). Moreover, BTLA, LIGHT, and CD160 can interfere with the binding of $\mathrm{gD}$ to HVEM, and inhibition of the HVEM/BTLA/LIGHT/CD160 pathway facilitates decreased HSV-1 latency and reactivation (142). The 


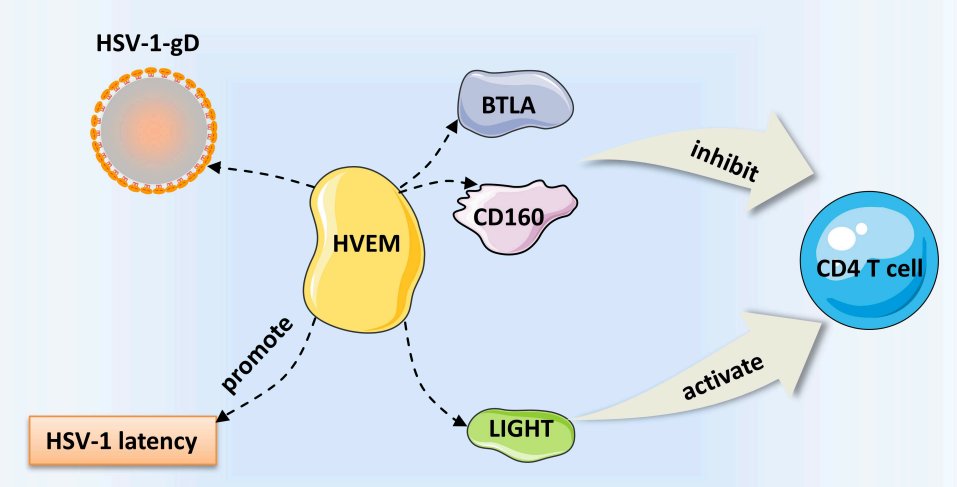

FIGURE 2 | Regulation of HSK by HVEM. HVEM can interact with immunoglobulin ligands [CD160, B, and T lymphocyte attenuator (BTLA)] and the tumor necrosis factor (TNF) ligand [LIGHT]. Binding of HVEM to LIGHT activates CD4+ T cells. Conversely, the interactions of CD160 and BTLA with HVEM inhibit CD4+ T cell expression. Besides, HVEM can promote the establishment of HSV-1 latency.

pathogenic mechanism of HVEM is a complicated process including aspects of viral replication, inflammation, the immune response, and viral latency. Based on our current understanding, we can consider HVEM as a treatment target for controlling the key steps of virus entry and immunomodulation (Figure 2).

\section{The Role of Hypoxia in HSK}

HSK is a chronic immune inflammatory disease. Large numbers of neutrophils and $\mathrm{CD}^{+}{ }^{+} \mathrm{T}$ cells are detected in the HSV-1infected corneal stroma. In the preclinical stage of HSK, increased expression of hypoxia-related glycolytic genes are detected in the corneas of HSV-1-infected mice, and viral replication in the infected cornea is triggered by innate immune responses during the early stage of infection, which induce neutrophil aggregation (143). Some studies have reported a correlation between hypoxia and inflammation. One of the causes of hypoxia in chronic inflammatory tissues may be the high metabolism of neutrophils, which consumes a large amount of energy, finally leading to tissue hypoxia. Thus, neutrophils are implicated in the development of hypoxia in the immunopathological process of HSK, and the degree of hypoxia is positively correlated with the number of neutrophils infiltrating the cornea. Moreover, tissue hypoxia can induce corneal angiogenesis, which aggravates visual impairment. Hypoxia inducible factors (HIFs) are present in the infected cornea, and blocking HIF- $1 \alpha$ and HIF- $2 \alpha$ expression with acriflavine can reduce the severity of HSK and induce regression of CNV (143). In summary, hypoxia plays an important role in HSK pathogenesis.

\section{CONCLUSION}

HSK is one of the leading causes of blindness, and activation of the virus during latency is recognized as the primary cause of recurrent HSK. After infection, the immune response is triggered as HSV enters the corneal epithelium. Homeostasis is maintained by pro-inflammatory and anti-inflammatory mediators in vivo. When this balance shifts to pro-inflammatory conditions, the cascade reaction mediated by inflammatory regulatory factors can lead to severe visual impairment, including corneal edema, stromal opacity, and corneal scarring due to inflammatory cell infiltration. In pro-inflammatory conditions, neutrophils can indirectly promote corneal hypoxia and directly aggravate the inflammatory process of corneal lesions. At present, there are few studies on hypoxia for HSK. Hypoxia is related to inflammation and can accelerate the formation of CNV. To date, the understanding of HSK pathogenesis is mainly based on experimental mouse models, and little is known about the effect of HSV-1 virus genotypes on clinical manifestations of human diseases. These studies provide important insights into the roles of host factors in the prevention and immunopathology of HSK. This review elaborates on the various pathogenic factors that may lead to HSK from the immunological and 
molecular levels. In addition to the cytokines and chemokines required for inflammatory immune responses, this review also emphasizes the important role of glycoproteins, SP, HVEM, hypoxia, and microRNAs in HSK pathogenesis. We believe that more pathogenic factors will be found in future scientific work, such as insulin-like growth factor-binding protein-3, which is present in the epithelium and stroma of HSK developing corneas and protects from aggravation of the lesions (144). It is important to have more in-depth research on hypoxia, microRNA, SP, and other areas to find more effective therapeutic targets for HSK and reduce the blindness rate.

\section{REFERENCES}

1. Rowe AM, St Leger AJ, Jeon S, Dhaliwal DK, Knickelbein JE, Hendricks RL. Herpes keratitis. Prog Retin Eye Res. (2013) 32:88-101. doi: 10.1016/j.preteyeres.2012.08.002

2. Hawthorne KM, Dana R, Chodosh J. Delayed type hypersensitivity in the pathogenesis of recurrent herpes stromal keratitis. Semin Ophthalmol. (2011) 26:246-50. doi: 10.3109/08820538.2011.588659

3. Farooq AV, Valyi-Nagy T, Shukla D. Mediators and mechanisms of herpes simplex virus entry into ocular cells. Curr Eye Res. (2010) 35:445-50. doi: $10.3109 / 02713681003734841$

4. El Kasmi I, Lippe R. Herpes simplex virus $1 \mathrm{gN}$ partners with gM to modulate the viral fusion machinery. J Virol. (2015) 89:2313-23. doi: 10.1128/JVI.03041-14

5. Shukla D, Spear PG. Herpesviruses and heparan sulfate: an intimate relationship in aid of viral entry. J Clin Invest. (2001) 108:503-10. doi: $10.1172 /$ jci200113799

6. Jaggi U, Wang S, Tormanen K, Matundan H, Ljubimov AV, Ghiasi H. Role of herpes simplex virus type 1 (HSV-1) Glycoprotein $\mathrm{K}(\mathrm{gK})$ pathogenic CD8(+) T cells in exacerbation of eye disease. Front Immunol. (2018) 9:2895. doi: 10.3389/fimmu.2018.02895

7. Xu D, Esko JD. Demystifying heparan sulfate-protein interactions. Annu Rev Biochem. (2014) 83:129-57. doi: 10.1146/annurev-biochem-060713-035314

8. Hadigal SR, Agelidis AM, Karasneh GA, Antoine TE, Yakoub AM, Ramani VC, et al. Heparanase is a host enzyme required for herpes simplex virus-1 release from cells. Nat Commun. (2015) 6:6985. doi: 10.1038/ncomms7985

9. Agelidis AM, Shukla D. Cell entry mechanisms of HSV: what we have learned in recent years. Future Virol. (2015) 10:1145-54. doi: 10.2217/fvl.15.85

10. Bacsa S, Karasneh G, Dosa S, Liu J, Valyi-Nagy T, Shukla D. Syndecan-1 and syndecan-2 play key roles in herpes simplex virus type-1 infection. J Gen Virol. (2011) 92:733-43. doi: 10.1099/vir.0.027052-0

11. Lobo AM, Agelidis AM, Shukla D. Pathogenesis of herpes simplex keratitis: the host cell response and ocular surface sequelae to infection and inflammation. Ocul Surf. (2019) 17:40-9. doi: 10.1016/j.jtos.2018.10.002

12. Bhela S, Varanasi SK, Jaggi U, Sloan SS, Rajasagi NK, Rouse BT. The plasticity and stability of regulatory t cells during viral-induced inflammatory lesions. J Immunol. (2017) 199:1342-52. doi: 10.4049/jimmunol.1700520

13. Rajasagi NK, Rouse BT. The role of t cells in herpes stromal keratitis. Front Immunol. (2019) 10:512. doi: 10.3389/fimmu.2019.00512

14. Maertzdorf J, Verjans GM, Remeijer L, van der Kooi A, Osterhaus $\mathrm{AD}$. Restricted $\mathrm{T}$ cell receptor beta-chain variable region protein use by cornea-derived CD4+ and CD8+ herpes simplex virus-specific $\mathrm{T}$ cells in patients with herpetic stromal keratitis. J Infect Dis. (2003) 187:550-8. doi: $10.1086 / 367991$

15. Xia L, Zhang S, Zhou J, Li Y. A crucial role for B and T lymphocyte attenuator in preventing the development of $\mathrm{CD} 4+\mathrm{T}$ cell-mediated herpetic stromal keratitis. Mol Vis. (2010) 16:2071-83

16. Rajasagi NK, Rouse BT. Application of our understanding of pathogenesis of herpetic stromal keratitis for novel therapy. Microbes Infect. (2018) 20:52630. doi: 10.1016/j.micinf.2017.12.014

17. Chen W, Tang Q, Hendricks RL. Ex vivo model of leukocyte migration into herpes simplex virus-infected mouse corneas. J Leukoc Biol. (1996) 60:167-73. doi: 10.1002/jlb.60.2.167

\section{AUTHOR CONTRIBUTIONS}

All authors listed have made a substantial, direct and intellectual contribution to the work, and approved the manuscript for publication.

\section{FUNDING}

This work was supported by the Provincial Office Bureau Project of Jilin Province (SCZSY201730; 3D518V563429).

18. Divito SJ, Hendricks RL. Activated inflammatory infiltrate in HSV-1-infected corneas without herpes stromal keratitis. Invest Ophthalmol Vis Sci. (2008) 49:1488-95. doi: 10.1167/iovs.07-1107

19. Jiang Y, Yin X, Stuart PM, Leib DA. dendritic cell autophagy contributes to herpes simplex virus-driven stromal keratitis and immunopathology. mBio. (2015) 6:e01426-15. doi: 10.1128/mBio.01426-15

20. Verjans GM, Remeijer L, Mooy CM, Osterhaus AD. Herpes simplex virusspecific $\mathrm{T}$ cells infiltrate the cornea of patients with herpetic stromal keratitis: no evidence for autoreactive T cells. Invest Ophthalmol Vis Sci. (2000) 41:2607-12

21. Keadle TL, Morris JL, Pepose JS, Stuart PM. CD4(+) and CD8(+) cells are key participants in the development of recurrent herpetic stromal keratitis in mice. Microb Pathog. (2002) 32:255-62. doi: 10.1006/mpat.2002.0506

22. Lepisto AJ, Frank GM, Xu M, Stuart PM, Hendricks RL. CD8 T cells mediate transient herpes stromal keratitis in CD4-deficient mice. Invest Ophthalmol Vis Sci. (2006) 47:3400-9. doi: 10.1167/iovs.05-0898

23. Zhang J, Liu H, Wei B. Immune response of $\mathrm{T}$ cells during herpes simplex virus type 1 (HSV-1) infection. J Zhejiang Univ Sci B. (2017) 18:277-88. doi: 10.1631/jzus.B1600460

24. Liu T, Khanna KM, Chen X, Fink DJ, Hendricks RL. CD8(+) T cells can block herpes simplex virus type 1 (HSV-1) reactivation from latency in sensory neurons. J Exp Med. (2000) 191:1459-66. doi: 10.1084/jem.191.9.1459

25. Mott KR, Allen SJ, Zandian M, Konda B, Sharifi BG, Jones C, et al. CD8 $\alpha$ dendritic cells drive establishment of HSV-1 latency. PLoS ONE. (2014) 9:e93444. doi: 10.1371/journal.pone.0093444

26. Matundan H, Mott KR, Ghiasi H. Role of CD8+ T cells and lymphoid dendritic cells in protection from ocular herpes simplex virus 1 challenge in immunized mice. J Virol. (2014) 88:8016-27. doi: 10.1128/JVI.0 0913-14

27. Stuart PM, Summers B, Morris JE, Morrison LA, Leib DA. CD8(+) T cells control corneal disease following ocular infection with herpes simplex virus type 1. J Gen Virol. (2004) 85:2055-63. doi: 10.1099/vir.0.80049-0

28. Stuart PM, Keadle TL. Recurrent herpetic stromal keratitis in mice: a model for studying human HSK. Clin Dev Immunol. (2012) 2012:728480. doi: 10.1155/2012/728480

29. Suryawanshi A, Veiga-Parga T, Rajasagi NK, Reddy PB, Sehrawat S, Sharma S, et al. Role of IL-17 and Th17 cells in herpes simplex virus-induced corneal immunopathology. J Immunol. (2011) 187:1919-30. doi: 10.4049/jimmunol.1100736

30. Veiga-Parga T, Sehrawat S, Rouse BT. Role of regulatory T cells during virus infection. Immunol Rev. (2013) 255:182-96. doi: 10.1111/imr.12085

31. Jaggi U, Varanasi SK, Bhela S, Rouse BT. On the role of retinoic acid in virus induced inflammatory response in cornea. Microbes Infect. (2018) 20:337-45. doi: 10.1016/j.micinf.2018.04.007

32. Varanasi SK, Reddy PBJ, Bhela S, Jaggi U, Gimenez F, Rouse BT. Azacytidine treatment inhibits the progression of herpes stromal keratitis by enhancing regulatory $t$ cell function. J Virol. (2017) 91:e02367-1. doi: 10.1128/JVI.02367-16

33. Kimura A, Kishimoto T. IL-6: regulator of treg/Th17 balance. Eur J Immunol. (2010) 40:1830-5. doi: 10.1002/eji.201040391

34. Suvas S, Azkur AK, Kim BS, Kumaraguru U, Rouse BT. CD4+CD25+ regulatory $\mathrm{T}$ cells control the severity of viral immunoinflammatory lesions. J Immunol. (2004) 172:4123-32. doi: 10.4049/jimmunol.172.7.4123 
35. Xia L, Tan T, Li Y, Zhong Q, Shi M. Blockade of IL-27 signaling ameliorates herpes stromal keratitis with upregulated CD4(+) Foxp3(+) regulatory T cells influx in mice. Indian J Ophthalmol. (2019) 67:1821-28. doi: 10.4103/ijo.IJO_1780_18

36. Veiga-Parga T, Suryawanshi A, Mulik S, Gimenez F, Sharma S, Sparwasser $\mathrm{T}$, et al. On the role of regulatory $\mathrm{T}$ cells during viral-induced inflammatory lesions. J Immunol. (2012) 189:5924-33. doi: 10.4049/jimmunol.1202322

37. Maertzdorf J, Osterhaus AD, Verjans GM. IL-17 expression in human herpetic stromal keratitis: modulatory effects on chemokine production by corneal fibroblasts. J Immunol. (2002) 169:5897-903. doi: 10.4049/jimmunol.169.10.5897

38. Kolls JK, Linden A. Interleukin-17 family members and inflammation. Immunity. (2004) 21:467-76. doi: 10.1016/j.immuni.2004.08.018

39. Xia L, Zhang $\mathrm{S}$, Cao $\mathrm{Z}$, Hu $\mathrm{Y}$, Yang $\mathrm{H}$, Wang $\mathrm{D}$. Interleukin17 enhanced immunoinflammatory lesions in a mouse model of recurrent herpetic keratitis. Microbes Infect. (2013) 15:126-39. doi: 10.1016/j.micinf.2012.10.017

40. Molesworth-Kenyon SJ, Yin R, Oakes JE, Lausch RN. IL-17 receptor signaling influences virus-induced corneal inflammation. J Leukoc Biol. (2008) 83:401-8. doi: 10.1189/jlb.0807571

41. Staats HF, Lausch RN. Cytokine expression in vivo during murine herpetic stromal keratitis. effect of protective antibody therapy. J Immunol. (1993) 151:277-283

42. Keadle TL, Usui N, Laycock KA, Miller JK, Pepose JS, Stuart PM. IL-1 and TNF-alpha are important factors in the pathogenesis of murine recurrent herpetic stromal keratitis. Invest Ophthalmol Vis Sci. (2000) 41:96-102

43. Minagawa H, Hashimoto K, Yanagi Y. Absence of tumour necrosis factor facilitates primary and recurrent herpes simplex virus-1 infections. J Gen Virol. (2004) 85:343-7. doi: 10.1099/vir.0.19627-0

44. Biswas PS, Banerjee K, Kim B, Rouse BT. Mice transgenic for IL-1 receptor antagonist protein are resistant to herpetic stromal keratitis: possible role for IL-1 in herpetic stromal keratitis pathogenesis. J Immunol. (2004) 172:373644. doi: 10.4049/jimmunol.172.6.3736

45. Fenton RR, Molesworth-Kenyon S, Oakes JE, Lausch RN. Linkage of IL-6 with neutrophil chemoattractant expression in virus-induced ocular inflammation. Invest Ophthalmol Vis Sci. (2002) 43:737-43

46. Hou A, Tong L. Expression, regulation, and effects of interleukin-17f in the human ocular surface. Ocul Immunol Inflamm. (2018) 26:1069-77. doi: 10.1080/09273948.2017.1316411

47. Rajasagi NK, Bhela S, Varanasi SK, Rouse BT. Frontline science: aspirin-triggered resolvin D1 controls herpes simplex virus-induced corneal immunopathology. J Leukoc Biol. (2017) 102:1159-71. doi: 10.1189/jlb.3HI1216-511RR

48. Tilg H, Dinarello CA, Mier JW. IL-6 and APPs: anti-inflammatory and immunosuppressive mediators. Immunol Today. (1997) 18:428-32. doi: 10.1016/s0167-569901103-1

49. West DM, Del Rosso CR, Yin XT, Stuart PM. CXCL1 but not IL-6 is required for recurrent herpetic stromal keratitis. J Immunol. (2014) 192:1762-7. doi: 10.4049/jimmunol.1302957

50. Bouley DM, Kanangat S, Wire W, Rouse BT. Characterization of herpes simplex virus type-1 infection and herpetic stromal keratitis development in IFN-gamma knockout mice. J Immunol. (1995) 155:3964-71

51. Inoue $\mathrm{T}$, Inoue $\mathrm{Y}$, Kosaki $\mathrm{R}$, Inoue $\mathrm{Y}$, Nishida $\mathrm{K}$, Shimomura $\mathrm{Y}$, et al. Immunohistological study of infiltrated cells and cytokines in murine herpetic keratitis. Acta Ophthalmol Scand. (2001) 79:484-7. doi: 10.1034/j.1600-0420.2001.790511.x

52. Wasmuth S, Bauer D, Steuhl KP, Heiligenhaus A. Topical antisenseoligonucleotides targeting IFN-gamma mRNA improve incidence and severity of herpetic stromal keratitis by cytokine specific and sequence unspecific effects. Graefes Arch Clin Exp Ophthalmol. (2008) 246:443-51. doi: 10.1007/s00417-007-0707-1

53. Minami M, Kita M, Yan XQ, Yamamoto $T$, Iida $T$, Sekikawa $K$, et al. Role of IFN-gamma and tumor necrosis factor-alpha in herpes simplex virus type 1 infection. J Interferon Cytokine Res. (2002) 22:671-6. doi: 10.1089/10799900260100150

54. Bigley NJ. Complexity of Interferon-gamma Interactions with HSV-1. Front Immunol. (2014) 5:15. doi: 10.3389/fimmu.2014.00015
55. Keadle TL, Alexander DE, Leib DA, Stuart PM. Interferon gamma is not required for recurrent herpetic stromal keratitis. Virology. (2008) 380:46-51. doi: 10.1016/j.virol.2008.07.018

56. Stumpf TH, Shimeld C, Easty DL, Hill TJ. Cytokine production in a murine model of recurrent herpetic stromal keratitis. Invest Ophthalmol Vis Sci. (2001) 42:372-8

57. Conrady CD, Jones $\mathrm{H}$, Zheng $\mathrm{M}$, Carr DJ. A functional type i interferon pathway drives resistance to cornea herpes simplex virus type 1 infection by recruitment of leukocytes. J Biomed Res. (2011) 25:111-9. doi: 10.1016/s1674-830160014-6

58. Sainz B Jr, Halford WP. Alpha/Beta interferon and gamma interferon synergize to inhibit the replication of herpes simplex virus type 1. J Virol. (2002) 76:11541-50. doi: 10.1128/jvi.76.22.11541-11550.2002

59. Sarangi PP, Sehrawat S, Suvas S, Rouse BT. IL-10 and natural regulatory T cells: two independent anti-inflammatory mechanisms in herpes simplex virus-induced ocular immunopathology. J Immunol. (2008) 180:6297-306. doi: 10.4049/jimmunol.180.9.6297

60. Tumpey TM, Cheng H, Yan XT, Oakes JE, Lausch RN. Chemokine synthesis in the HSV-1-infected cornea and its suppression by interleukin-10. J Leukoc Biol. (1998) 63:486-92. doi: 10.1002/jlb.63.4.486

61. Keadle TL, Stuart PM. Interleukin-10 (IL-10) ameliorates corneal disease in a mouse model of recurrent herpetic keratitis. Microb Pathog. (2005) 38:13-21. doi: 10.1016/j.micpath.2004.09.003

62. Yan XT, Zhuang M, Oakes JE, Lausch RN. Autocrine action of IL-10 suppresses proinflammatory mediators and inflammation in the HSV-1infected cornea. J Leukoc Biol. (2001) 69:149-57

63. Ghasemi H, Ghazanfari T, Yaraee R, Owlia P, Hassan ZM, Faghihzadeh S. Roles of IL-10 in ocular inflammations: a review. Ocul Immunol Inflamm. (2012) 20:406-18. doi: 10.3109/09273948.2012.723109

64. Rajasagi NK, Suryawanshi A, Sehrawat S, Reddy PB, Mulik S, Hirashima $M$, et al. Galectin-1 reduces the severity of herpes simplex virusinduced ocular immunopathological lesions. J Immunol. (2012) 188:463143. doi: 10.4049/jimmunol.1103063

65. Ghiasi H, Cai S, Slanina SM, Perng GC, Nesburn AB, Wechsler SL. The role of interleukin (IL)-2 and IL-4 in herpes simplex virus type 1 ocular replication and eye disease. J Infect Dis. (1999) 179:1086-93. doi: $10.1086 / 314736$

66. Osorio Y, Sharifi BG, Perng G, Ghiasi NS, Ghiasi H. The role of $T(H) 1$ and $\mathrm{T}(\mathrm{H}) 2$ cytokines in HSV-1-induced corneal scarring. Ocul Immunol Inflamm. (2002) 10:105-16. doi: 10.1076/ocii.10.2.105.13982

67. Palomino DC, Marti LC. Chemokines and immunity. Einstein. (2015) 13:469-73. doi: 10.1590/S1679-45082015RB3438

68. Allen SJ, Crown SE, Handel TM. Chemokine: receptor structure, interactions, and antagonism. Annu Rev Immunol. (2007) 25:787-820. doi: 10.1146/annurev.immunol.24.021605.090529

69. Spandau UH, Toksoy A, Verhaart S, Gillitzer R, Kruse FE. High expression of chemokines Gro-alpha (CXCL-1), IL-8 (CXCL-8), and MCP-1 (CCL-2) in inflamed human corneas in vivo. Arch Ophthalmol. (2003) 121:825-31. doi: 10.1001/archopht.121.6.825

70. Bryant-Hudson KM, Carr DJ. CXCL1-deficient mice are highly sensitive to pseudomonas aeruginosa but not herpes simplex virus type 1 corneal infection. Invest Ophthalmol Vis Sci. (2012) 53:6785-92. doi: $10.1167 /$ iovs.12-10400

71. Srivastava R, Khan AA, Chilukuri S, Syed SA, Tran TT, Furness J, et al. CXCL10/CXCR3-dependent mobilization of herpes simplex virus-specific $\mathrm{CD}^{+} \mathrm{T}_{\mathrm{EM}}$ and $\mathrm{CD} 8^{+} \mathrm{T}_{\mathrm{RM}}$ Cells within infected tissues allows efficient protection against recurrent herpesvirus infection and disease. J Virol. (2017) 91:e00278-17. doi: 10.1128/JVI.00278-17

72. Shen FH, Wang SW, Yeh TM, Tung YY, Hsu SM, Chen SH. Absence of CXCL10 aggravates herpes stromal keratitis with reduced primary neutrophil influx in mice. J Virol. (2013) 87:8502-10. doi: 10.1128/JVI. 01198-13

73. Khan AA, Srivastava R, Vahed H, Roy S, Walia SS, Kim GJ, et al. Human asymptomatic epitope peptide/CXCL10-based prime/pull vaccine induces herpes simplex virus-specific gamma interferon-positive $\mathrm{CD} 107^{+} \mathrm{CD} 8^{+} \mathrm{T}$ cells that infiltrate the corneas and trigeminal ganglia of humanized HLA transgenic rabbits and protect against ocular herpes challenge. J Virol. (2018) 92:e00535-18. doi: 10.1128/JVI.00535-18 
74. Khan AA, Srivastava R, Chentoufi AA, Kritzer E, Chilukuri S, Garg S, et al. Bolstering the number and function of HSV-1-Specific CD8(+) effector memory $\mathrm{T}$ cells and tissue-resident memory $\mathrm{T}$ cells in latently infected trigeminal ganglia reduces recurrent ocular herpes infection and disease. $J$ Immunol. (2017) 199:186-203. doi: 10.4049/jimmunol.1700145

75. Tajfirouz D, West DM, Yin XT, Potter CA, Klein R, Stuart PM. CXCL9 compensates for the absence of CXCL10 during recurrent herpetic stromal keratitis. Virology. (2017) 506:7-13. doi: 10.1016/j.virol.2017.02.022

76. Molesworth-Kenyon SJ, Milam A, Rockette A, Troupe A, Oakes JE, Lausch RN. Expression, inducers and cellular sources of the chemokine MIG (CXCL 9), during primary herpes simplex virus type-1 infection of the cornea. Curr Eye Res. (2015) 40:800-8. doi: 10.3109/02713683.2014.957779

77. Wuest T, Austin BA, Uematsu S, Thapa M, Akira S, Carr DJ. Intact TRL 9 and type I interferon signaling pathways are required to augment HSV-1 induced corneal CXCL9 and CXCL10. J Neuroimmunol. (2006) 179:46-52. doi: 10.1016/j.jneuroim.2006.06.020

78. Wuest T, Farber J, Luster A, Carr DJ. CD4+ T cell migration into the cornea is reduced in CXCL9 deficient but not CXCL10 deficient mice following herpes simplex virus type 1 infection. Cell Immunol. (2006) 243:83-9. doi: 10.1016/j.cellimm.2007.01.001

79. Rowe AM, Yun H, Treat BR, Kinchington PR, Hendricks RL. Subclinical herpes simplex virus type 1 infections provide site-specific resistance to an unrelated pathogen. J Immunol. (2017) 198:1706-17. doi: 10.4049/jimmunol.1601310

80. Komatsu K, Miyazaki D, Morohoshi K, Kuo CH, Kakimaru-Hasegawa A, Komatsu N, et al. Pathogenesis of herpetic stromal keratitis in CCR5- and/or CXCR3-deficient mice. Curr Eye Res. (2008) 33:736-49. doi: 10.1080/02713680802344716

81. Conrady CD, Zheng M, Mandal NA, van Rooijen N, Carr DJ. IFN-alphadriven CCL2 production recruits inflammatory monocytes to infection site in mice. Mucosal Immunol. (2013) 6:45-55. doi: 10.1038/mi.2012.46

82. Lee SK, Choi BK, Kang WJ, Kim YH, Park HY, Kim KH, et al. MCP-1 derived from stromal keratocyte induces corneal infiltration of CD4+ T cells in herpetic stromal keratitis. Mol Cells. (2008) 26:67-73

83. Kim B, Sarangi PP, Lee Y, Deshpande Kaistha S, Lee S, Rouse BT. Depletion of MCP-1 increases development of herpetic stromal keratitis by innate immune modulation. J Leukoc Biol. (2006) 80:1405-15. doi: 10.1189/jlb.0406295

84. Stuart PM, Morris JE, Sidhu M, Keadle TL. CCL3 protects mice from corneal pathology during recurrent HSV-1 infection. Front Biosci. (2008) 13:4407-15. doi: $10.2741 / 3013$

85. Carr DJ, Ash J, Lane TE, Kuziel WA. Abnormal immune response of CCR5deficient mice to ocular infection with herpes simplex virus type 1. J Gen Virol. (2006) 87(Pt 3):489-99. doi: 10.1099/vir.0.81339-0

86. Musarrat F, Jambunathan N, Rider PJF, Chouljenko VN, Kousoulas KG. The amino terminus of herpes simplex virus 1 glycoprotein $\mathrm{K}(\mathrm{gK})$ is required for $\mathrm{gB}$ binding to Akt, release of intracellular calcium, and fusion of the viral envelope with plasma membranes. J Virol. (2018) 92:e01842-17. doi: 10.1128/JVI.01842-17

87. Wang S, Ghiasi H. Absence of signal peptide peptidase, an essential herpes simplex virus 1 glycoprotein $\mathrm{k}$ binding partner, reduces virus infectivity in vivo. J Virol. (2019) 93:e01309-19. doi: 10.1128/JVI.01309-19

88. He J, Cosby R, Hill JM, Bazan HE. Changes in corneal innervation after HSV1 latency established with different reactivation phenotypes. Curr Eye Res. (2017) 42:181-6. doi: 10.3109/02713683.2016.1167919

89. David AT, Baghian A, Foster TP, Chouljenko VN, Kousoulas KG. The herpes simplex virus type 1 (HSV-1) glycoprotein $\mathrm{K}(\mathrm{gK})$ is essential for viral corneal spread and neuroinvasiveness. Curr Eye Res. (2008) 33:455-67. doi: 10.1080/02713680802130362

90. Saied AA, Chouljenko VN, Subramanian R, Kousoulas KG. A replication competent $\mathrm{HSV}-1$ (McKrae) with a mutation in the aminoterminus of glycoprotein $\mathrm{K}(\mathrm{gK})$ is unable to infect mouse trigeminal ganglia after cornea infection. Curr Eye Res. (2014) 39:596-603. doi: 10.3109/02713683.2013.855238

91. Allen SJ, Mott KR, Ghiasi H. Overexpression of herpes simplex virus glycoprotein $\mathrm{K}(\mathrm{gK})$ alters expression of $\mathrm{HSV}$ receptors in ocularly-infected mice. Invest Ophthalmol Vis Sci. (2014) 55:2442-51. doi: $10.1167 /$ iovs.14-14013
92. Allen SJ, Mott KR, Matsuura Y, Moriishi K, Kousoulas KG, Ghiasi $\mathrm{H}$. Binding of HSV-1 glycoprotein $\mathrm{K}(\mathrm{gK})$ to signal peptide peptidase (SPP) is required for virus infectivity. PLoS ONE. (2014) 9:e85360. doi: 10.1371/journal.pone.0085360

93. Allen SJ, Mott KR, Ljubimov AV, Ghiasi H. Exacerbation of corneal scarring in HSV-1 gK-immunized mice correlates with elevation of CD8+CD25+ $\mathrm{T}$ cells in corneas of ocularly infected mice. Virology. (2010) 399:11-22. doi: 10.1016/j.virol.2009.12.011

94. Mott KR, Chentoufi AA, Carpenter D, BenMohamed L, Wechsler SL, Ghiasi $\mathrm{H}$. The role of a glycoprotein K (gK) CD8+ T-cell epitope of herpes simplex virus on virus replication and pathogenicity. Invest Ophthalmol Vis Sci. (2009) 50:2903-12. doi: 10.1167/iovs.08-2957

95. Osorio Y, Mott KR, Jabbar AM, Moreno A, Foster TP, Kousoulas KG, et al. Epitope mapping of HSV-1 glycoprotein $\mathrm{K}(\mathrm{gK})$ reveals a $\mathrm{T}$ cell epitope located within the signal domain of gK. Virus Res. (2007) 128:71-80. doi: 10.1016/j.virusres.2007.04.007

96. Osorio Y, Cai S, Hofman FM, Brown DJ, Ghiasi H. Involvement of CD8+ T-cells in exacerbation of corneal scarring in mice. Curr Eye Res. (2004) 29:145-51. doi: 10.1080/02713680490504632

97. Mott KR, Osorio Y, Maguen E, Nesburn AB, Wittek AE, Cai S, et al. Role of anti-glycoproteins D (anti-gD) and K (anti-gK) IgGs in pathology of herpes stromal keratitis in humans. Invest Ophthalmol Vis Sci. (2007) 48:2185-93. doi: 10.1167/iovs.06-1276

98. Duan R, van Dun JM, Remeijer L, Siemerink M, Mulder PG, Norberg P, et al. Prevalence of herpes simplex virus type 1 glycoprotein $\mathrm{G}(\mathrm{gG})$ and gI genotypes in patients with herpetic keratitis. Br J Ophthalmol. (2008) 92:1195-200. doi: 10.1136/bjo.2007.136044

99. Yoshida M, Hosogai M, Yokokura S, Sato K, Hariya T, Kobayashi W, et al. Bilateral necrotizing herpes simplex keratitis in an immunocompetent patient with genetic analysis of herpes simplex virus 1. Cornea. (2019) 38:1185-8. doi: 10.1097/ICO.0000000000002026

100. Twardy BS, Channappanavar R, Suvas S. Substance P in the corneal stroma regulates the severity of herpetic stromal keratitis lesions. Invest Ophthalmol Vis Sci. (2011) 52:8604-13. doi: 10.1167/iovs.11-8089

101. Hazlett LD, Jiang X, McClellan SA. IL-10 function, regulation, and in bacterial keratitis. J Ocul Pharmacol Ther. (2014) 30:373-80. doi: 10.1089/jop.2014.0018

102. Suvas S. Role of Substance P Neuropeptide in inflammation, wound healing, and tissue homeostasis. J Immunol. (2017) 199:1543-52. doi: 10.4049/jimmunol.1601751

103. Gaddipati S, Rao P, Jerome AD, Burugula BB, Gerard NP, Suvas S. Loss of neurokinin-1 receptor alters ocular surface homeostasis and promotes an early development of herpes stromal keratitis. J Immunol. (2016) 197:402133. doi: 10.4049/jimmunol.1600836

104. Sun J, Ramnath RD, Bhatia M. Neuropeptide substance P upregulates chemokine and chemokine receptor expression in primary mouse neutrophils. Am J Physiol Cell Physiol. (2007) 293:C696-704. doi: 10.1152/ajpcell.00060.2007

105. Sloniecka M, Le Roux S, Zhou Q, Danielson P. Substance P enhances keratocyte migration and neutrophil recruitment through interleukin-8. Mol Pharmacol. (2016) 89:215-25. doi: 10.1124/mol.115.101014

106. Barbariga M, Fonteyne P, Ostadreza M, Bignami F, Rama P, Ferrari G. Substance P modulation of human and murine corneal neovascularization. Invest Ophthalmol Vis Sci. (2018) 59:1305-12. doi: 10.1167/iovs.1723198

107. Bignami F, Giacomini C, Lorusso A, Aramini A, Rama P, Ferrari G. NK1 receptor antagonists as a new treatment for corneal neovascularization. Invest Ophthalmol Vis Sci. (2014) 55:6783-94. doi: 10.1167/iovs.14-14553

108. Mulik S, Bhela S, Rouse BT. Potential function of miRNAs in herpetic stromal keratitis. Invest Opthalmol Vis Sci. (2013) 54:563-73. doi: 10.1167/iovs.12-11094

109. Bhela S, Rouse BT. Are miRNAs critical determinants in herpes simplex virus pathogenesis? Microbes Infect. (2018) 20:461-65. doi: 10.1016/j.micinf.2017.12.007

110. Bhela S, Mulik S, Gimenez F, Reddy PB, Richardson RL, Varanasi $\mathrm{SK}$, et al. Role of miR-155 in the pathogenesis of herpetic stromal keratitis. Am J Pathol. (2015) 185:1073-84. doi: 10.1016/j.ajpath.201 4.12.021 
111. Mulik S, Xu J, Reddy PB, Rajasagi NK, Gimenez F, Sharma S, et al. Role of miR-132 in angiogenesis after ocular infection with herpes simplex virus. Am J Pathol. (2012) 181:525-34. doi: 10.1016/j.ajpath.2012.04.014

112. Lagos D, Pollara G, Henderson S, Gratrix F, Fabani M, Milne RS, et al. miR-132 regulates antiviral innate immunity through suppression of the p300 transcriptional co-activator. Nat Cell Biol. (2010) 12:513-9. doi: $10.1038 / \mathrm{ncb} 2054$

113. Jiang X, Brown D, Osorio N, Hsiang C, Li L, Chan L, et al. A herpes simplex virus type 1 mutant disrupted for microRNA H2 with increased neurovirulence and rate of reactivation. J Neurovirol. (2015) 21:199-209. doi: 10.1007/s13365-015-0319-1

114. Xu S, Hazlett LD. MicroRNAs in ocular infection. Microorganisms. (2019) 7:359. doi: 10.3390/microorganisms7090359

115. Mukwaya A, Jensen L, Peebo B, Lagali N. MicroRNAs in the cornea: Role and implications for treatment of corneal neovascularization. Ocul Surf. (2019) 17:400-11. doi: 10.1016/j.jtos.2019.04.002

116. Roshandel D, Eslani M, Baradaran-Rafii A, Cheung AY, Kurji K, Jabbehdari $\mathrm{S}$, et al. Current and emerging therapies for corneal neovascularization. Ocul Surf. (2018) 16:398-414. doi: 10.1016/j.jtos.2018.06.004

117. Zhang J, Wang S, He Y, Yao B, Zhang Y. Regulation of matrix metalloproteinases 2 and 9 in corneal neovascularization. Chem Biol Drug Des. (2020) 95:485-92. doi: 10.1111/cbdd.13529

118. Suryawanshi A, Mulik S, Sharma S, Reddy PB, Sehrawat S, Rouse BT. Ocular neovascularization caused by herpes simplex virus type 1 infection results from breakdown of binding between vascular endothelial growth factor A and its soluble receptor. J Immunol. (2011) 186:3653-65. doi: 10.4049/jimmunol.1003239

119. Koujah L, Suryawanshi RK, Shukla D. Pathological processes activated by herpes simplex virus-1 (HSV-1) infection in the cornea. Cell Mol Life Sci. (2019) 76:405-19. doi: 10.1007/s00018-018-2938-1

120. Suryawanshi A, Veiga-Parga T, Reddy PB, Rajasagi NK, Rouse BT. IL-17A differentially regulates corneal vascular endothelial growth factor (VEGF)-A and soluble VEGF receptor 1 expression and promotes corneal angiogenesis after herpes simplex virus infection. J Immunol. (2012) 188:3434-46. doi: 10.4049/jimmunol.1102602

121. Li Y, Zhou Y. Interleukin-17: the role for pathological angiogenesis in ocular neovascular diseases. Tohoku J Exp Med. (2019) 247:87-98. doi: 10.1620/tjem.247.87

122. Zhu Y, Tan W, Demetriades AM, Cai Y, Gao Y, Sui A, et al. Interleukin-17A neutralization alleviated ocular neovascularization by promoting M2 and mitigating M1 macrophage polarization. Immunology. (2016) 147:414-28. doi: 10.1111/imm.12571

123. Biswas PS, Banerjee K, Kinchington PR, Rouse BT. Involvement of IL-6 in the paracrine production of VEGF in ocular HSV-1 infection. Exp Eye Res. (2006) 82:46-54. doi: 10.1016/j.exer.2005.05.001

124. Banerjee K, Biswas PS, Kim B, Lee S, Rouse BT. CXCR2-/- mice show enhanced susceptibility to herpetic stromal keratitis: a role for IL-6-induced neovascularization. J Immunol. (2004) 172:1237-45. doi: 10.4049/jimmunol.172.2.1237

125. Gurung HR, Carr MM, Bryant K, Chucair-Elliott AJ, Carr DJ. Fibroblast growth factor-2 drives and maintains progressive corneal neovascularization following HSV-1 infection. Mucosal Immunol. (2018) 11:172-85. doi: $10.1038 / \mathrm{mi} .2017 .26$

126. Kim B, Lee S, Suvas S, Rouse BT. Application of plasmid DNA encoding IL18 diminishes development of herpetic stromal keratitis by antiangiogenic effects. J Immunol. (2005) 175:509-16. doi: 10.4049/jimmunol.175.1.509

127. Lee S, Zheng M, Kim B, Rouse BT. Role of matrix metalloproteinase- 9 in angiogenesis caused by ocular infection with herpes simplex virus. J Clin Invest. (2002) 110:1105-11. doi: 10.1172/jci0215755

128. Gimenez F, Mulik S, Veiga-Parga T, Bhela S, Rouse BT. Robo 4 counteracts angiogenesis in herpetic stromal keratitis. PLoS ONE. (2015) 10:e0141925. doi: 10.1371/journal.pone.0141925

129. Orita T, Kimura K, Zhou HY, Nishida T. Poly(I:C)-induced adhesion molecule expression mediated by NF-\{kappa\}B and phosphoinositide 3-kinase-Akt signaling pathways in human corneal fibroblasts. Invest Ophthalmol Vis Sci. (2010) 51:5556-60. doi: 10.1167/iovs.09-4909

130. Liu Y, Kimura K, Yanai R, Chikama T, Nishida T. Cytokine, chemokine, and adhesion molecule expression mediated by MAPKs in human corneal fibroblasts exposed to poly(I:C). Invest Ophthalmol Vis Sci. (2008) 49:333644. doi: 10.1167/iovs.07-0972

131. Li H, Zhang J, Kumar A, Zheng M, Atherton SS, Yu FS. Herpes simplex virus 1 infection induces the expression of proinflammatory cytokines, interferons and TLR7 in human corneal epithelial cells. Immunology. (2006) 117:167-76. doi: 10.1111/j.1365-2567.2005.02275.x

132. Zhu S, Xu X, Wang L, Su L, Gu Q, Wei F, et al. Inhibitory effect of a novel peptide, H-RN, on keratitis induced by LPS or poly(I:C) in vitro and in vivo via suppressing NF-kappaB and MAPK activation. J Transl Med. (2017) 15:20. doi: 10.1186/s12967-017-1121-z

133. Mauri DN, Ebner R, Montgomery RI, Kochel KD, Cheung TC, Yu GL, et al. LIGHT, a new member of the TNF superfamily, and lymphotoxin alpha are ligands for herpesvirus entry mediator. Immunity. (1998) 8:21-30. doi: 10.1016/s1074-761380455-0

134. Sedy JR, Gavrieli M, Potter KG, Hurchla MA, Lindsley RC, Hildner K, et al. $\mathrm{B}$ and $\mathrm{T}$ lymphocyte attenuator regulates $\mathrm{T}$ cell activation through interaction with herpesvirus entry mediator. Nat Immunol. (2005) 6:90-8. doi: $10.1038 /$ nil 144

135. Cai G, Anumanthan A, Brown JA, Greenfield EA, Zhu B, Freeman GJ. CD160 inhibits activation of human CD4+ T cells through interaction with herpesvirus entry mediator. Nat Immunol. (2008) 9:176-85. doi: 10.1038/ni1554

136. Edwards RG, Longnecker R. herpesvirus entry mediator and ocular herpesvirus infection: more than meets the eye. J Virol. (2017) 91:e00115-17. doi: 10.1128/JVI.00115-17

137. Whitbeck JC, Peng C, Lou H, Xu R, Willis SH, Ponce de Leon M, et al. Glycoprotein D of herpes simplex virus (HSV) binds directly to HVEM, a member of the tumor necrosis factor receptor superfamily and a mediator of HSV entry. J Virol. (1997) 71:6083-93

138. Karaba AH, Kopp SJ, Longnecker R. Herpesvirus entry mediator is a serotype specific determinant of pathogenesis in ocular herpes. Proc Natl Acad Sci USA. (2012) 109:20649-54. doi: 10.1073/pnas.1216967109

139. Edwards RG, Kopp SJ, Karaba AH, Wilcox DR, Longnecker R. Herpesvirus entry mediator on radiation-resistant cell lineages promotes ocular herpes simplex virus 1 pathogenesis in an entry-independent manner. mBio. (2015) 6:e01532-15. doi: 10.1128/mBio.01532-15

140. Guo H, Pang K, Wei Y, Yi C, Wu X. Herpes virus entry mediator in human corneal epithelial cells modulates the production of inflammatory cytokines in response to HSV type 1 challenge. Ophthalmic Res. (2015) 54:128-34. doi: $10.1159 / 000437209$

141. Allen SJ, Rhode-Kurnow A, Mott KR, Jiang X, Carpenter D, RodriguezBarbosa JI, et al. Interactions between herpesvirus entry mediator (TNFRSF14) and latency-associated transcript during herpes simplex virus 1 latency. J Virol. (2014) 88:1961-71. doi: 10.1128/JVI.02467-13

142. Wang S, Ljubimov AV, Jin L, Pfeffer K, Kronenberg M, Ghiasi H. Herpes simplex virus 1 latency and the kinetics of reactivation are regulated by a complex network of interactions between the herpesvirus entry mediator, its ligands (gD, BTLA, LIGHT, and CD160), and the latency-associated transcript. J Virol. (2018) 92:e01451-18. doi: 10.1128/JVI.01451-18

143. Rao P, Suvas S. development of inflammatory hypoxia and prevalence of glycolytic metabolism in progressing herpes stromal keratitis lesions. J Immunol. (2019) 202:514-26. doi: 10.4049/jimmunol.18 00422

144. Rao P, Suvas PK, Jerome AD, Steinle JJ, Suvas S. Role of insulin-like growth factor binding protein-3 in the pathogenesis of herpes stromal keratitis. Invest Ophthalmol Vis Sci. (2020) 61:46. doi: 10.1167/iovs.61.2.46

Conflict of Interest: The authors declare that the research was conducted in the absence of any commercial or financial relationships that could be construed as a potential conflict of interest.

Copyright (c) 2020 Wang, Wang, Xu and Zhou. This is an open-access article distributed under the terms of the Creative Commons Attribution License (CC BY). The use, distribution or reproduction in other forums is permitted, provided the original author(s) and the copyright owner(s) are credited and that the original publication in this journal is cited, in accordance with accepted academic practice. No use, distribution or reproduction is permitted which does not comply with these terms. 